\title{
Demographic and morphological shrinkage of urban neighbourhoods in a post-socialist city: the case of Łódź, Poland
}

\author{
Jarosław Kazimierczak \& Ewa Szafrańska
}

To cite this article: Jarosław Kazimierczak \& Ewa Szafrańska (2019) Demographic and morphological shrinkage of urban neighbourhoods in a post-socialist city: the case of Łódź, Poland, Geografiska Annaler: Series B, Human Geography, 101:2, 138-163, DOI: 10.1080/04353684.2019.1582304

To link to this article: https://doi.org/10.1080/04353684.2019.1582304

Published online: 27 Feb 2019.

Submit your article to this journal $\sqsubset$

Џ Article views: 60

View Crossmark data ¿ 


\title{
Demographic and morphological shrinkage of urban neighbourhoods in a post-socialist city: the case of Łódź, Poland
}

\author{
Jarosław Kazimierczak (D) and Ewa Szafrańska \\ Institute of Urban Geography and Tourism Studies, Faculty of Geographical Sciences, University of Łódź, Łódź, \\ Poland
}

\begin{abstract}
The paper contributes to the discussion concerning methods used to analyse urban shrinkage and points to the need to comprehensively examine the reasons, course and effects of the process by expanding the research perspective with morphological aspect. In accordance with theoretical assumption adopted for this paper, morphology acts as an element that complements demographic changes in the identification of urban shrinkage since the observed quantitative and qualitative changes in the urban fabric are indicative of the direction of economic and social transformations in cities. The paper aims at identifying the course of shrinkage in a selected post-socialist CEE city and discusses demographic and morphological ways of identifying the process. Łódź (Poland), one of the largest and the fastest shrinking cities in the CEE region was selected for the case study. The paper provides intra-urban scale analyses conducted at the level of individual neighbourhoods taking account of quantitative and qualitative changes in demographic and morphological structure of the city. The picture of changes at a neighbourhood level has helped identify spatial traits of urban shrinkage experienced throughout the city. Spatial scope of the area that undergoes demographic and morphological shrinkage was confronted with the crisis area intended for regeneration within the policy pursued by the city.
\end{abstract}

\section{ARTICLE HISTORY}

Received 20 January 2018

Revised 7 February 2019

Accepted 11 February 2019

\section{KEYWORDS}

Urban decline; demographic and morphological urban shrinkage; intra-urban scale of analysis; urban regeneration areas; postsocialist city; Łódź

\section{Introduction}

Urban shrinkage is a theoretical concept, which implies a multifaceted crisis of a particular city (Haase, Vaishar, and Węcławowicz 2011; Martinez-Fernandez et al. 2012; Musterd and Bontje 2012; Reckien and Martinez-Fernandez 2011; Stryjakiewicz, Ciesiółka, and Jaroszewska 2012). The view is reflected in the definition of a shrinking city worked out by the Shrinking Cities International Research Network (SCIRN), ${ }^{1}$ according to which such city experiences a significant outflow of population (more than $0.15 \%$ annually over at least 5 years) and, on the other hand, it undergoes economic transformations with signs of structural crisis (Stryjakiewicz 2013). Stryjakiewicz et al. (2014) explain that the structural economic crisis is linked with a high unemployment rate, degradation of residential resources, and particular intensification of social problems. Other suggested conditions of urban shrinkage include social, political and administrative changes (Grossmann et al. 2008; Wiechmann and Bontje 2015), as well as specific (incidental) factors, such as armed conflicts and natural catastrophes (Krzysztofik et al. 2015; Oswalt and Rieniets 2006). Reasons behind urban shrinkage are mostly complex, distributed in time or short-term and usually rapid. 
Urban shrinkage is a global phenomenon (Martinez-Fernandez et al. 2016). The idea has propagated world-wide triggering researchers' interest in the subject and leading to numerous comparative studies (inter alia Cunningham-Sabot and Fol 2009; Haase et al. 2016; Haase, Rink, and Grossmann 2016; Turok and Mykhnenko 2007, 2008). They aim at identifying homogenous and heterogeneous characteristics of urban shrinkage at global, regional and national scale with gradual deviating from studies on individual cities. At the same time, we can observe a tendency to identify urban shrinkage based only on the population criterion. It is also caused by unrestricted access to demographic statistics, which undoubtedly facilitates comparisons between cities. However, by assuming that depopulation is the optimal and often the only one aspect of analysis that helps identify shrinking cities we 'dilute' the essence of urban shrinkage. In such cases, we can speak of depopulating cities, since 'shrinking' is a much more complex process. Such theoretical and methodological approach finds numerous opponents among experts in the field, e.g. Audirac, Cunningham-Sabot, and Fol (2012), Martinez-Fernandez et al. (2012) and Wiechmann and Pallagst (2012). Haase et al. (2014) argue that the approach is incorrect and results from the misunderstanding of the very idea of urban shrinkage. They seek to explain the problem with the complexity of urban shrinkage and imprecisely defined relationships between the process and other factors provoking broadly understood urban decline that further leads to depopulation of cities. In their studies, they pay special attention to five concepts: stage or life-cycle theories of urban development, suburbanization, accumulation of capital and its spatial-temporal circulation, territorial divisions of labour, and second demographic transition (SDT).

Within this context, the aim of this paper is to contribute to the debate about the essence of urban shrinkage concept, its key dimensions and the scale of analysis of the process taking a closer look at the case of a post-socialist city of Łódź in Poland. The study covers a series of surveys on how population and the housing stock evolved, both understood as complementary aspects that help identify urban shrinkage. Following Klassen (1988), we assumed that the shrinkage of urban built-up areas reflects poor social and economic condition of the city. The assumption is crucial from the viewpoint of the demographic and morphological method adopted to identify urban shrinkage. Such approach is extremely rare in studies on urban shrinkage as usually degradation and demolition of the housing stock are interpreted only as consequences rather than causes of depopulation while in fact they may be elements of the process (Hoekveld 2012; Stryjakiewicz et al. 2014). On top of that, we carried out integrated demographic and morphological studies on an intra-urban scale, i.e. for urban neighbourhoods. They helped us identify the actually shrinking urban areas and provided a response as to where and how the city has been shrinking (on the example of Łódź within its administrative borders).

\section{Urban shrinkage: the concept behind methodological approaches}

\section{Urban shrinkage in the demographic approach: scale and scope of analysis}

Urban studies focused on the shrinkage of cities are conducted at three levels of analysis (Figure 1). Regional scale comparative studies, which enable pinpointing differences and similarities in the origin, course and effects of depopulation of a specific group of cities are carried out in the widest context (e.g. Beauregard 2009; Turok and Mykhnenko 2007, 2008; Wiechmann and Pallagst 2012). Such approach helps proposing general conclusions, as well as detailed conceptual and theoretical assumptions, provided the list of reasons for the shrinkage of cities contains factors other than depopulation. At a lower level there are general urban studies (urban and supra-urban scale), which identify: causes (i.a., Couch et al. 2005; Nuissl and Rink 2005; Reckien and Martinez-Fernandez 2011), course and dynamics (i.a., Turok and Mykhnenko 2007, 2008), as well as effects of depopulation (i.a., Couch and Cocks 2011; Fol 2012; Koziol 2004). In a heuristic model of urban shrinkage Haase et al. (2014) distinguish between direct and indirect effects of depopulation. They are relevant for local growth, especially in the context of planning (Dewar and Thomas 


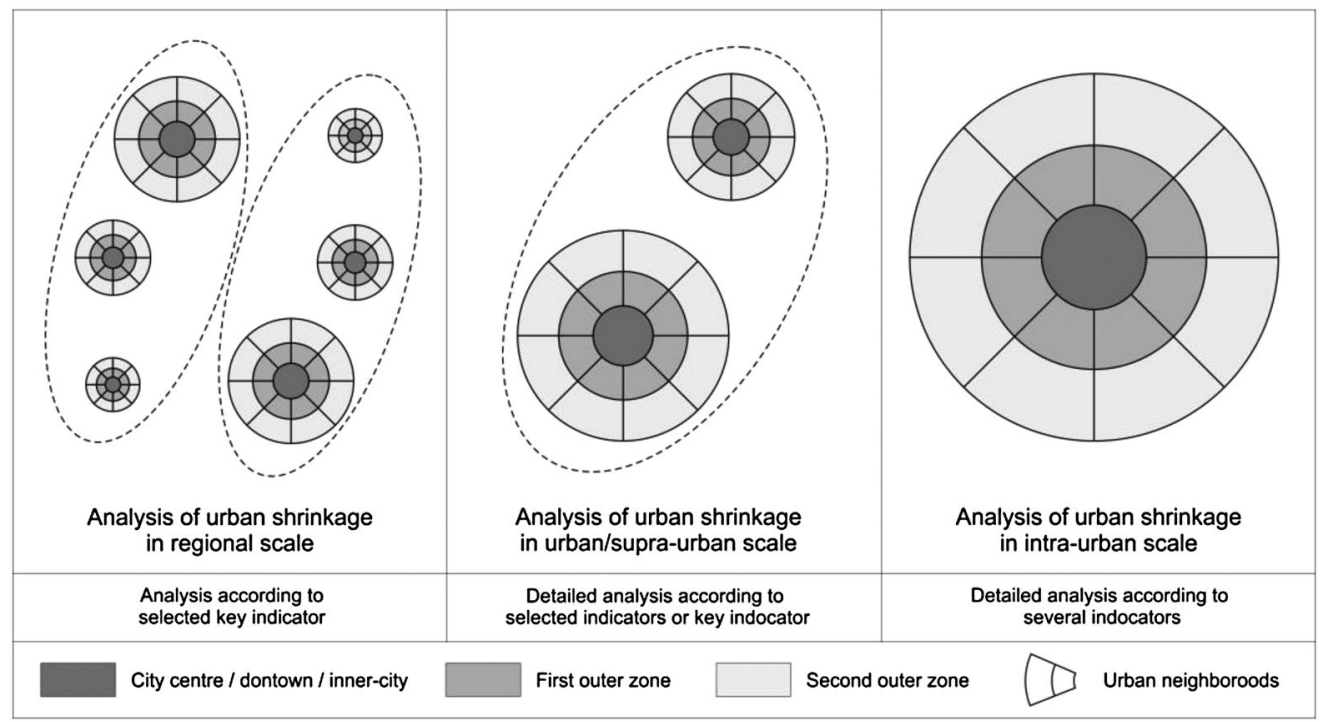

Figure 1. Scale of analysis of urban shrinkage process (Source: authors' original work).

2013; Jessen 2012), while their results provide a powerful cognitive and practical input. The last one and the lowest level of analysis is that of intra-urban scale studies, i.e. on a scale of a particular district, urban zone or housing estate, which can be compared with one another across the city. But since for such studies, it is needed more data other than changes in the population, intra-urban scale studies are the most rare even though they give the most precise picture of analysed reality (e.g. Temelová et al. 2016). As stressed by, inter alia, Martinez-Fernandez et al. (2016) results of these studies, due to their cognitive and explanatory merits, can be applied in urban development planning of the city and of its specific areas. Integrated studies at all three levels of investigation provide the picture of the substance of urban shrinkage.

Changes in population remain the common criterion for studies at different levels. However, studies carried out so far have not produced universal patterns of urban depopulation, including the depopulation of post-socialist cities in Europe. Current knowledge helps us conclude that depopulation of post-socialist cities in Europe tackled medium-sized and larege cities (usually with the exception of capital cities), such as Łódź, while at the same time the population of large cities in Western Europe continued to increase (Turok and Mykhnenko 2007, 2008). Haase, Rink, and Grossmann (2016) attempted to systemize attributes of depopulation in cities of the former Eastern Bloc based on studies conducted by other researchers, such as Bernt et al. (2014), Couch et al. (2012) and Haase et al. (2016). Systemic transformation was the first attribute as the de facto catalyst of urban depopulation. Its direct negative repercussions included, inter alia, economic crises and the loss of jobs, mainly in industry, leading to the impoverishment of societies, reduced fertility rate and economic migration. On the other hand, under the conditions of market economy urban residents have become more entrepreneurial and the most successful among them quickly started to accumulate wealth. The rise of the middle class is a positive effect of transformation. Asignificant part of this 'new class' of relatively wealthy people adopted Northern American and Western European lifestyle and moved into single-family houses in the outskirts, something that for economic reasons was unimaginable in the communist times (Stryjakiewicz 2013). These lifestyle changes stimulated urban-to-rural migrations, mostly to suburban areas, and finally urban sprawl of postsocialist cities (Cirtautas 2013; Geshkov 2015; Novák and Sýkora 2007; Špačková, Dvořácková, and Tobrmanová 2016). When analysing suburbanization in a wider context we need to pay attention to the fact that modern cities are not confined to their administrative boarders but they operate 
within functional zones (urban regions and/or metropolitan regions). Grasping the real, not illusionary, outflow of residents from a city is a vital issue emerging in studies on depopulation of cities. Daily migrations of those who inhabit suburban zones connect with commuting to work, schools, cultural institutions or healthcare centres based in the city. In this context, the loss of residents caused by suburbanization does not have to produce effects known from literature, such as closing public institutions (e.g. schools, theatres, hospitals) or commercial establishments (e.g. restaurants, shops). On the contrary, depopulation of certain districts may reduce housing deficit or eliminate the problem of insufficient capacity of public kindergartens. Thus, apparently the outflow of residents cannot be interpreted as the single and arbitrary criterion of urban shrinkage, which in a wider context should be linked with structural crisis.

To properly identify the shrinking areas it is needed to capture the real outflow of population not only from the city and its functional zone but also from the neighbourhoods; this approach is crucial for intra-urban scale analyses. The difficulty frequently encountered in the latter is the absence of quantitative data, which hinders or even impedes capturing intra-urban migration flows not only between the inner-city and urban hinterland but also between individual urban neighbourhoods. The essence of studies at the intra-urban scale consists in identifying changes in demographic structures of individual urban areas. Specific importance of these studies lies in highlighting social and economic segregation and gentrification (Marcińczak et al. 2013) which provide information that is crucial for urban development (recovery) planning.

Studies on urban shrinkage based exclusively on population data often suffer from low credibility. The case of Poland has revealed gaps resulting from imperfect public statistics. As argued by Śleszyński (2005) births and deaths registers give precise numbers but migration statistics (in- and out-migrations) is incomplete. It is highly likely that access to high-quality population data is a problem not only in Poland but also in other post-socialist CEECs. ${ }^{2}$

In the light of the above considerations and methodological concerns, the discourse about the essence of urban shrinkage should stress the need for developing criteria other than population data to identify shrinking cities. These other criteria should be easily available similarly to population statistics. In the case study of Łódź we used data showing changes in urban housing stock available for individual urban neighbourhoods.

\section{Morphological approach to urban shrinkage analysis}

The assumption, according to which changes in urban housing stock reflect social and economic condition of cities and their neighbourhoods takes the thesis proposed by Klassen (1988) as its point of departure. The thesis argues that gradual social development generates some inertia, which impedes rapid changes in spatial structures leading to an increasing discrepancy between their qualities, on the one hand, and needs and requirements of societies. It means cities include areas that are little attractive either as a place to live or as a setting for other urban functions: economic, social, cultural, and leisure. If the mismatch is a long-term one, they experience further decapitalization. $^{3}$ Aiello, Ardone, and Scopelliti (2010) claim that the lack of satisfaction with housing quality, a factor crucial for the quality of life, may be decisive for a decision to move elsewhere. Grossmann et al. (2014) add that the outflow of residents reduces investment (also that of property developers) in depopulating locations, which, in turn, exacerbates critical condition of the area. As a result, affluent people leave the neighbourhood leaving poorer community in degraded urban tissue, which initiates or enhances socio-economic segregation.

Most studies on urban shrinkage blame depopulation for the degradation of urban housing stock, also for the increasing number of vacant houses, be it housing or service property, (Hoekveld 2012; Stryjakiewicz et al. 2014). In extreme cases depopulation leads to the demolition of degraded and idle housing stock necessary to rationalize urban management (Haase, Rink, and Grossmann 2016), examples of which can be found in cities in Eastern Germany (Bernt 2009; Radzimski 2016; Wiechmann 2009). Degradation of buildings undermines the quality of public space and urban landscape. 
Taking Klassen's (1988) concept of mismatching urban and social subsystems, which implies that there are cities or neighbourhoods that are less attractive to live in or use than others as the starting point, we must assume that the quality of property and public space is an important factor, which impacts migration in cities and in their neighbourhoods.

In the light of the above considerations, one-way dependency frequently pointed to in literature, according to which depopulation leads to the degradation of urban housing stock cannot be confirmed. Moreover, we may conclude that poor quality of urban space importantly impacts negative migration balance (direct consequence) and, indirectly, reduces the birth rate predominantly because mostly young people, whose mobility is naturally higher, move out by which they deepen negative demographic situation and decrease the number of births. In the CEE countries that experienced rapid systemic transformations, the phenomenon can be explained with the impact of 'transformation shock' upon reproductive behaviour characterized by the delay in motherhood and the reduced number of children per family considered within the concept of the SDT (Lesthaeghe and van de Kaa 1986; Van de Kaa 2003). As reported by Brainerd (2012) the relationship between economic uncertainty and reproductive behaviour, although indirect, was found in post-socialist countries during the first decade of transformation. Groups the most tackled with negative effects of transformation included communities the most vulnerable in economic and social terms residing in degraded housing stock. The principle applies to individual neighbourhoods and the city as a whole. Poor quality of urban space is also decisive for the 'escape' of economic operators to more attractive areas. As a result, we put forward a thesis, according to which the loss and degradation of urban housing stock are valid aspects indicative of urban shrinkage. Together with analysis of changes in the population on an intra-urban scale they help identify urban shrinkage. Thus, an integrated analysis of shrinkage at demographic and morphological planes may become one of the tools used to optimize urban development plans. At the theoretical and conceptual level it bridges concepts that explain urban decline with traditional approach to urban shrinkage concept based mainly on the examination into population changes.

\section{Morphological and demographic development of Łódź: brief introduction into the case study}

According to Yin (2014), the selection of a particular case study is dictated either by its uniqueness or universality or by both at the same time. The latter offers a better opportunity to be able to interpret the results of the study in a wider context of the issue at hand. The case of Łódź meets both criteria of uniqueness and universality.

The history of Łódź dates back to the 14th century but it remained a small agricultural town until the early nineteenth century. At that time Łódź started to host the textile industry, which provided impetus for dynamic growth of the city (Young and Kaczmarek 2008). Over several dozen years Łódź - a settlement with 331 residents - transformed into the second largest Polish city in 1815. In 1880 the city was inhabited by 253.000 people. ${ }^{4}$ The dynamics of demographic development of industrial Łódź can be compared only to fast industrializing American cities from the same period (Liszewski, Liszewski, and Young 1997). It also acquired many traits of American cities, such as the grid of streets and big urban blocks. In 1940 Łódź was inhabited by 672,000 people. That is why its growth was far from typical, evolutionary multiannual development path of most European cities.

After World War II Łódź developed and functioned as a typical state-socialist city (see Szelényi 1996) that was subject to the same systemic influences as other large cities in the CEE countries. These influences included: strenuous industrialization, total subordination to the central government, absence of market economy, subordination of social and spatial development to ideological priorities, strong migration flows from rural regions, and structural housing shortage mitigated by building large prefabricated housing districts. Compared to other large cities in Poland, Łódź remained almost intact by World War II and after 1945 its dwelling stock was not destroyed (Table 1). However, its standard was (and still is) poor (Table 2), especially in the city centre, due 
to historical circumstances and the rate of growth of the city in the second half of the nineteenth century, unprecedented elsewhere in Europe which transformed it into a big industrial centre. The biggest number of residents in the city - 854,300 people (Figure 2) - was reported in 1988 . At that time the average was 2.7 residents per unit of dwelling in Łódź. Data from 2002 show that although the availability of the dwelling stock in Łódź was relatively better than in other large cities in Poland (Table 3), the quality of housing was much lower (Tables 2 and 3).

Territorial expansion of the city followed increases in its population. Spatial and functional structure of the centre of Łódź, i.e. the central area (SW) and downtown 'collar' (Figure 3) with the oldest and the most degraded houses of contemporary Łódź developed in the years 1840-1906 (Table 4). Areas incorporated into Łódź following WWII were mostly non-urbanized and over the communist rule they got partly built-up with modernist housing districts accompanied by industrial areas, which together provided a closer outer zone of the city. It was a planned development typical of most cities in the countries of the then Eastern Bloc (Monclús and Díez Medina 2016; Szafrańska 2013). Housing districts from that period are Chojny-Zatorze, Dąbrowa, Olechów, Radogoszcz, Retkinia, Teofilów, Widzew Wschód, Żubardź, and Zarzew. The latest expansion of administrative borders of Łódź took place in 1988 when rural and rural-urban areas were incorporated into the city. After systemic transformation in 1989 they became areas of inner city suburbanization. At the same time, more distant peripheral zone of the city emerged.

Over the years 1820-2016 there were three cases when Łódź reported the loss of population. They were linked with World Wars I and II and with economic crisis following the systemic transformation in 1989 and the collapse of textile monoculture resulting from the fall of the Soviet Union - the main market for Łódź textile output (Figure 2). Economic distress suffered by the city in the 1990s produced extremely high structural unemployment, impoverished local communities, negative migration balance, ageing society and very low birth rate (Table 5). In the period 1988-2016 Łódź lost 157,500 inhabitants accounting for $18.46 \%$ of its population. On average it was losing 5833 people annually, i.e. $-0.75 \%{ }^{5}$ The highest loss was recorded in: $2009(-10,805), 2010(-11,754)$, and 2014 (-7856) (Figure 4). The case of Łódź replicates the course of development observed in other cities in the CEE region after 1990 where systemic transformation led to a deep social and economic crisis exacerbated by globalization. These consequences were especially painful to old industrial cities, such as Łódź. However, we need to bear in mind that depopulation of Łódź is linked predominantly with negative birth rate rather than with negative migration balance (Table 5).

According to the classification proposed by Turok and Mykhnenko (2007), following 25 years of continuous depopulation Łódź belongs to the group of cities of long-term decline. Unique situation of the city is confirmed by the scale of depopulation, which amounted to $18.43 \%$ over the period 1989-2016, making it the fastest depopulating large city in Poland and one of the fastest depopulating cities in Europe. ${ }^{6}$ Its depopulation has its roots in the times before 1989 and has been fuelled by very poor standard of living including crowded flats and, first and foremost, very poor quality of the dwelling stock. After WWII and in the 1990s repairs of the pre-war urban tissue - which was substantially worn out and represented a vast proportion of the dwelling stock - got largely neglected. Outlays earmarked for repairs in Łódź were much smaller than in other large Polish cities, ${ }^{7}$ which contributed to progressing decapitalization of municipal housing stock and made living conditions still less favourable than in other cities.

Table 1. Dwelling stock in Łódź in 2002 by age (in \%).

\begin{tabular}{lcr}
\hline Flats built in respective periods & Polish cities & Łódź \\
\hline before 1944 & 21.7 & 26.6 \\
$1945-1970$ & 22.3 & 30.4 \\
$1971-1978$ & 42.0 & 23.6 \\
$1979-2002$ & 22.6 & 10.5 \\
Total & 100.0 & 100.0 \\
\hline
\end{tabular}

Source: authors' compilation based on National Census 2002. 
Table 2. Utilities, sanitary and technical installations and equipment available in flats in 2010 (in \%).

\begin{tabular}{lccr}
\hline Utilities & Poland & Polish cities & Łódź \\
\hline Water & 95.50 & 98.48 & 96.87 \\
Flush toilet & 88.26 & 94.65 & 89.54 \\
Bathroom & 87.18 & 92.43 & 85.43 \\
Gas & 56.40 & 73.86 & 81.94 \\
Central heating & 78.55 & 85.03 & 79.04 \\
\hline
\end{tabular}

Source: authors' compilation based on Statistics Poland.

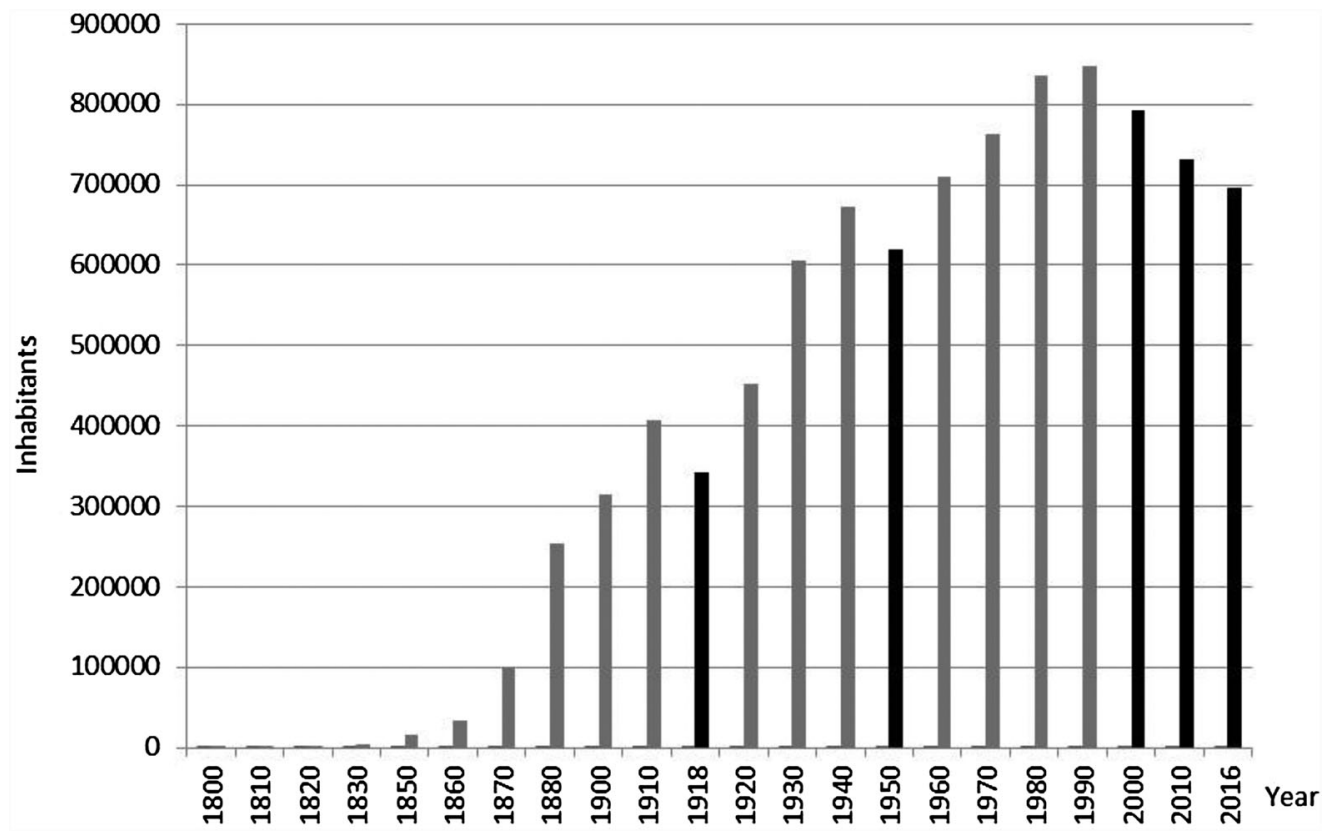

Figure 2. Population change in Łódź from 1800 to 2016 (Source: authors' compilation based on Statistics Poland and Historia Polski w liczbach. Ludność. Terytorium 1994).

Table 3. Quality of dwellings in Łódź compared to other large cities in Poland in the years 2002-2013.

\begin{tabular}{|c|c|c|c|c|c|c|c|c|c|c|}
\hline \multirow{2}{*}{ Categories } & \multicolumn{2}{|c|}{ Łódź } & \multicolumn{2}{|c|}{ Warsaw } & \multicolumn{2}{|c|}{ Kraków } & \multicolumn{2}{|c|}{ Wrocław } & \multicolumn{2}{|c|}{ Poznań } \\
\hline & 2002 & 2013 & 2002 & 2013 & 2002 & 2013 & 2002 & 2013 & 2002 & 2013 \\
\hline Population in thousands & 789.3 & 711.3 & 1688.2 & 1724.4 & 757.5 & 759.0 & 639.1 & 632.1 & 577.1 & 548.0 \\
\hline Flats per 1000 people & 403 & 484 & 425 & 514 & 371 & 456 & 374 & 459 & 370 & 446 \\
\hline Average flat area in $\mathrm{m}^{2}$ & 52.1 & 53.7 & 55.5 & 58.8 & 55.5 & 57.7 & 60.1 & 70.8 & 62.5 & 64.9 \\
\hline Average flat area in $\mathrm{m}^{2}$ per person & 21.1 & 26.3 & 23.6 & 30.2 & 20.6 & 26.3 & 21.3 & 32.5 & 23.1 & 28.9 \\
\hline No. of rooms per flat & 3.1 & 3.1 & 3.2 & 3.2 & 3.2 & 3.2 & 3.6 & 3.9 & 3.5 & 3.5 \\
\hline No. of persons per flat & 2.5 & 2.0 & 2,4 & 1.9 & 2.7 & 2.2 & 2.8 & 2.2 & 2.7 & 2.2 \\
\hline
\end{tabular}

Source: authors' compilation based on National census 2002 and Statistics Poland.

Nowadays, Łódź is a typical post-socialist city experiencing intensive political and socio-economic transformation over the last quarter century. According to Sýkora (2009: 394), 'post-socialist cities are cities at the transition stage. They are characterized by dynamic processes of change rather than static patterns. The urban environment formed under the previous system is being adapted and remodelled to match the new conditions of the political, economic, and cultural transition towards the capitalist society. [...] The contradictions between the capitalist rules and the socialist urban 

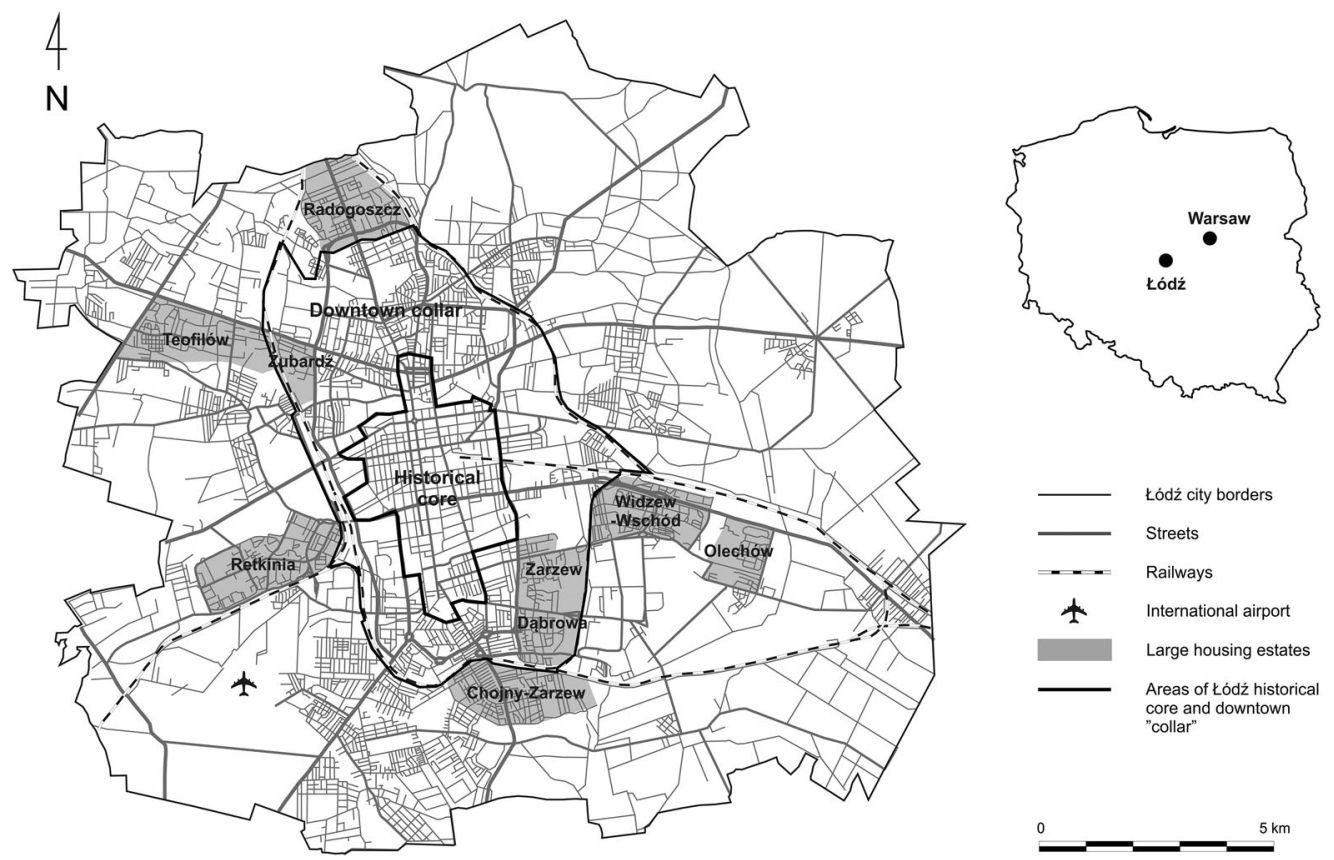

Figure 3. Morphological structure of Łódź in 2013 (Source: authors' compilation).

Table 4. Housing stock by age in development areas in Łódź in 2002 (in \%).

\begin{tabular}{|c|c|c|c|c|c|c|c|c|}
\hline \multirow[b]{2}{*}{ Area } & \multicolumn{6}{|c|}{ Buildings constructed in: } & \multirow[b]{2}{*}{$\begin{array}{l}\text { Under constru-ction } \\
\text { in } 2002 \\
\end{array}$} & \multirow[b]{2}{*}{$\begin{array}{c}\text { Un-known } \\
\text { age }\end{array}$} \\
\hline & $\begin{array}{c}\text { Be-fore } \\
1918\end{array}$ & $\begin{array}{c}1918- \\
1944\end{array}$ & $\begin{array}{c}1945- \\
1970\end{array}$ & $\begin{array}{c}1971- \\
1978\end{array}$ & $\begin{array}{c}1979- \\
1988\end{array}$ & $\begin{array}{c}1989- \\
2001\end{array}$ & & \\
\hline Łódź & 12.7 & 22.1 & 27.5 & 10.9 & 11.2 & 12.2 & 3.0 & 0.4 \\
\hline Historical core & 60.0 & 23.5 & 10.1 & 3.5 & 1.3 & 1.3 & 0.0 & 0.3 \\
\hline $\begin{array}{l}\text { Downtown } \\
\text { 'collar' }\end{array}$ & 18.9 & 34.7 & 32.5 & 7.6 & 2.8 & 2.7 & 0.3 & 0.5 \\
\hline $\begin{array}{l}\text { Outer zones (I- } \\
\text { IV) }\end{array}$ & 4.1 & 18.0 & 28.5 & 12.9 & 15.3 & 16.7 & 4.2 & 0.4 \\
\hline
\end{tabular}

Source: authors' compilation based on National census 2002.

environment led to the restructuring of the existing urban areas. With time, new capitalist urban developments are having more and more influence on the whole urban organization'.

\section{Methodology}

\section{Methodological assumptions}

The key question in the research is: what was the course of the shrinkage of Łódź following systemic transformations in 1989 and where the process occurred? Three hypotheses have been adopted for the study. According to the first one $\left(\mathrm{H}_{1}\right)$, only some neighbourhoods in Łódź suffered from depopulation, while the remaining ones reported population increases. The intensity rate of depopulation in depopulating units was higher than the increase in population in growing units, meaning the whole city was classified as depopulating (shrinking). The second hypothesis $\left(\mathrm{H}_{2}\right)$ assumes that depopulating neighbourhoods in Łódź only partly overlapped with units where the loss in urban housing stock was observed. In line with the third hypothesis $\left(\mathrm{H}_{3}\right)$, the territorial scope of neighbourhoods in Łódź, which suffered from morphological and demographic decline over the period 1988-2013 significantly coincides with the degraded area identified as such by the Łódź City Council and earmarked 
Table 5. Selected indicators describing social and economic performance of Łódź compared to other big cities in Poland in the years 2002 and 2016.

\begin{tabular}{|c|c|c|c|c|c|c|c|c|c|c|}
\hline \multirow{2}{*}{ Indicator } & \multicolumn{2}{|c|}{ Łódź } & \multicolumn{2}{|c|}{ Warsaw } & \multicolumn{2}{|c|}{ Kraków } & \multicolumn{2}{|c|}{ Wrocław } & \multicolumn{2}{|c|}{ Poznań } \\
\hline & 2002 & 2016 & 2002 & 2016 & 2002 & 2016 & 2002 & 2016 & 2002 & 2016 \\
\hline $\begin{array}{l}\text { Gross average monthly salary in } \\
\text { PLN }\end{array}$ & 2102 & 4230 & 3238 & 5740 & 2301 & 4635 & 2299 & 4801 & 2395 & 4771 \\
\hline $\begin{array}{l}\text { Gross average monthly salary as a } \\
\text { fraction of national average } \\
\text { (Poland }=100)\end{array}$ & 93.9 & 98.6 & 144.6 & 133.8 & 102.7 & 108.0 & 102.6 & 111.9 & 106.9 & 111.2 \\
\hline Unemployment rate & 18.4 & 7.9 & 6.2 & 2.6 & 7.5 & 3.5 & 12.3 & 2.7 & 6.7 & 1.9 \\
\hline $\begin{array}{l}\text { Share of population in post- } \\
\text { working age }\end{array}$ & 19.2 & 26.6 & 19.5 & 23.7 & 16.6 & 22.7 & 17.4 & 23.3 & 16.3 & 23.4 \\
\hline $\begin{array}{l}\text { Demographic burden index - } \\
\text { post-working age population } \\
\text { per } 100 \text { persons in pre-working } \\
\text { age }\end{array}$ & 121.6 & 184.0 & 124.3 & 137.9 & 94.4 & 140.0 & 104.2 & 147.7 & 93.4 & 144.4 \\
\hline Migration balance & -801 & -832 & 6413 & 7615 & 1839 & 1807 & 635 & 2028 & -686 & -1808 \\
\hline Birth rate & -4924 & -3520 & -5295 & 2468 & -957 & 1665 & 1525 & 646 & -1229 & 543 \\
\hline
\end{tabular}

Source: authors' compilation based on Local Data Bank.

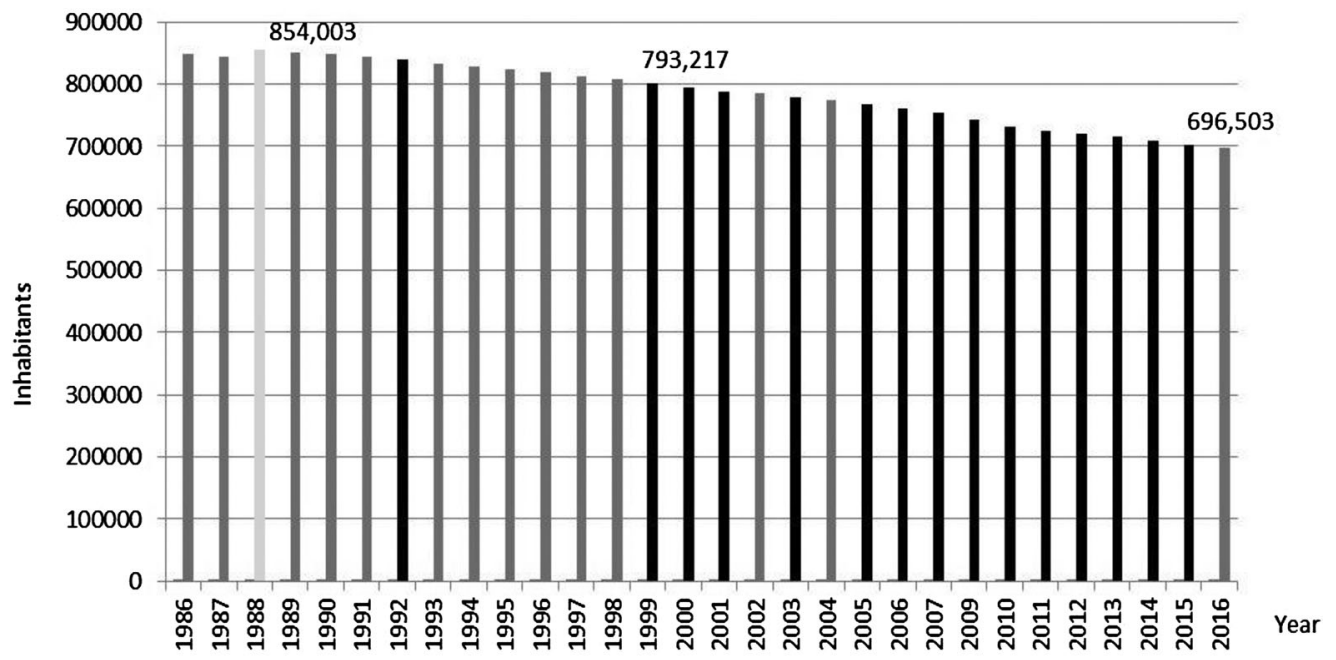

Light gray: top number of inhabitants. Grey: decline from $-0,18 \%$ to $-0,75 \%$. Black: decline over $-0,75 \%$.

Figure 4. Population change in Łódź from 1986 to 2016 (Source: authors' compilation based on Statistics Poland).

for urban regeneration. All these hypotheses will be taken as foundations, around which we will be explaining the case study in a wider theoretical and methodological context (E). Below we present graphic representation of the research problem stated for the case study of Łódź, integrating traditional (based on demographic changes) and alternative (based on compound morphological and demographic changes) approaches to urban shrinkage (Figure 5).

Methodology-wise, the paper discusses a single case study, in which we identified three units of analysis: (1) shrinking housing areas (neighbourhoods) based on population criterion (data); (2) shrinking neighbourhoods based on a combined population and morphological criterion (data), and (3) actually shrinking neighbourhoods (depopulation and the loss of the housing stock) against the backdrop of the area formally designated by the Łódź City Council as degraded and envisaged for regeneration (area tackled with structural decline). The case study of Łódź will demonstrate: (1) differences in the identification of shrinking neighbourhoods depending on data used for the exercise and (2) actually shrinking neighbourhoods and their spatial relations with areas suffering from structural decline. 


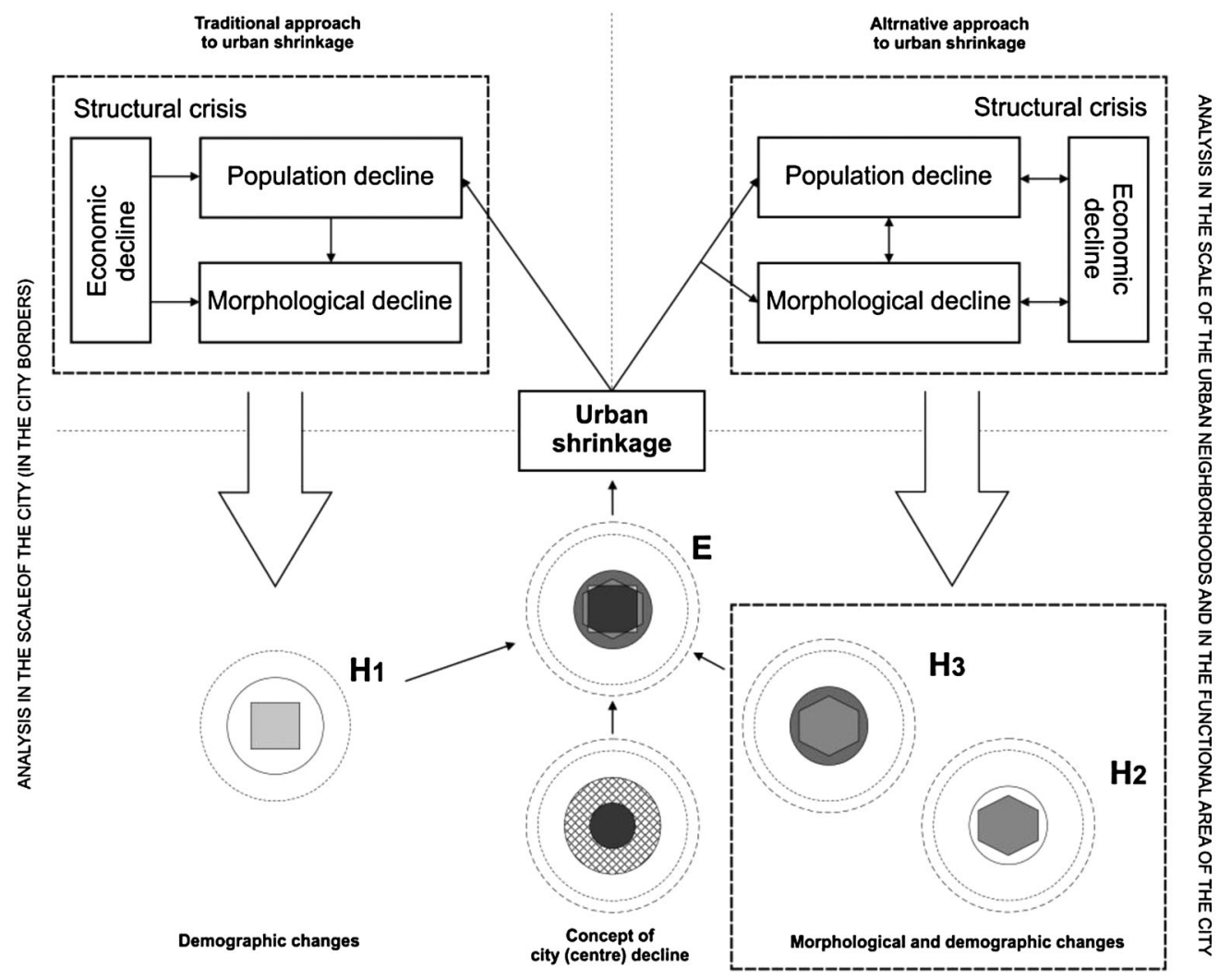

Figure 5. Conceptual and methodological framework for the research problem (Source: authors' original work).

\section{Data sources and methods of analysis}

The study uses three aggregated categories of data: (1) demographic changes over the years 19882013 (population); (2) changes in the housing stock in the period 1988-2013 including changes in the dwelling stock in 1988-2013 as the main data used in the analysis and changes in the number of houses over the years 1988-2002 as complementary data, and (3) changes in urban fabric in the years 1994-2011 (number of buildings: residential, industrial, service, special). These three categories of data are the identification criteria for shrinking areas in Łódź.

Data come primarily from National Censuses of 1988 and 2002. They inform about the size of Łódź population, dwelling stock and the number of houses by the period of construction. Data are aggregated for urban units, which are the smallest spatial units that enable analysing data from these three periods. The latest National Census conducted in Poland in 2011 provides aggregated data only for districts, i.e. much bigger spatial units. That prevented us from comparing 2011 data with data from earlier censuses. Changes in population statistics and in the dwelling stock have been extended until 2013 using independent statistics of the Łódź City Council and Łódź Statistical Office. These data, however, are aggregated for the so-called neighbourhood units, i.e. in between urban units (from National Censuses of 1988 and 2002) and districts (from 2011 National Census). Thus, we aggregated all statistics used in the case of Łódź study at the same intermediary level.

Other data used in the research related to changes in the housing fabric. They are collected by the Łódź Planning Office and come from remote sensing exercises carried out in the periods 1994-2009 and 2009-2011. The Łódź Planning Office has not got any more up-to-date statistics. 
The analysis of changes in population and in the dwelling stock covers the years 1988-2013, changes in the number of available houses were followed over the period 1988-2002, while changes in the urban fabric were analysed for the period 1994-2011. Statistics for 2014 and the following years for each of our units of analysis are either unavailable or they cannot be aggregated for neighbourhoods. We decided that 25 years is a sufficient period for an analysis to grasp the relationship between demographic and morphological changes that have taken place in Łódź and lie at the heart of the case study in question.

The research also interpreted planning documentation of the Łódź City Council taking into account urban policies in order to counteract depopulation of the city and its technical and functional degradation in the second and third decade of the twenty-first century. Among these documents were Łódź Local Regeneration Programme in 2007-2013, Łódź Municipal Regeneration Programme 2026+, City Spatial Development Strategy until 2020+, Łódź Housing Policy 2020+, and Conditions and Directions of Spatial Development of Łódź of 2010. Analysis of population-related and morphological data covered also qualitative categories, such as demographic structure of city residents and their economic standing as well as technical condition, age and type of housing as well as availability of utilities in flats. Quality data were examined as part of complementary analysis and used in interpretation of results of quantity research.

In the course of data collection we conducted triangulation of data (different categories of data), theoretical triangulation (different theoretical approaches that help identify shrinking areas), and methodological triangulation (quantitative and qualitative methods). Results of the research are presented in tables and then developed into thematic maps attached to the paper.

Being fully aware of all shortcomings and limitations, we selected data and analytical methods based on their universality, which allows applying the same research procedure to any other case study. Repeatability of the methodology ensures comparability of obtained results and helps formulate general theoretical statements.

\section{Study areas and units of analysis}

In the case study at hand, spatial analyses were carried out for 61 neighbourhoods within administrative borders of Łódź (Figure 6). They were delimited in the early 1990s based on historical and contemporary settlement units (districts, villages, settlements), meaning they are relatively homogenous when it comes to morphology. However, it does not mean that the neighbourhoods are homogenous in social and economic terms. The second key criterion for their delimitation was the population ceiling of 40,000 people.

In spatial analysis conducted for the city there are the following reference points for demographic and morphological changes identified in neighbourhoods: historical centre defined in the Strategy for Spatial Development of Łódź 2020+ with its central area (Polish: Strefa Wielkomiejska - SW), the so-called downtown 'collar', described in the same document as the downtown area (Polish: Obszar Współczesnego Rozwoju Strefy Wielkomiejskiej (OWRSW)), and the outer zone of the city (Figure 6). From the methodological point of view, delimitation of the historic city centre and the 'collar' was rather problematic as their borders are not identical with the borders of neighbourhood units. Finally, for the needs of this paper, the borders of the two zones were delimitated based on morphological and functional qualities of the neighbourhoods, including the age of the housing stock (see Table 4). City centre is the area with the oldest urban housing stock and the highest horizontal intensity. Downtown collar is the area in between the city centre and the ring rail line of Łódź, which may be considered identical with the territorial coverage of the nineteenth-century industrial city. The area is highly diversified in terms of morphology and functions much less, however, than the outer zone of the city. 


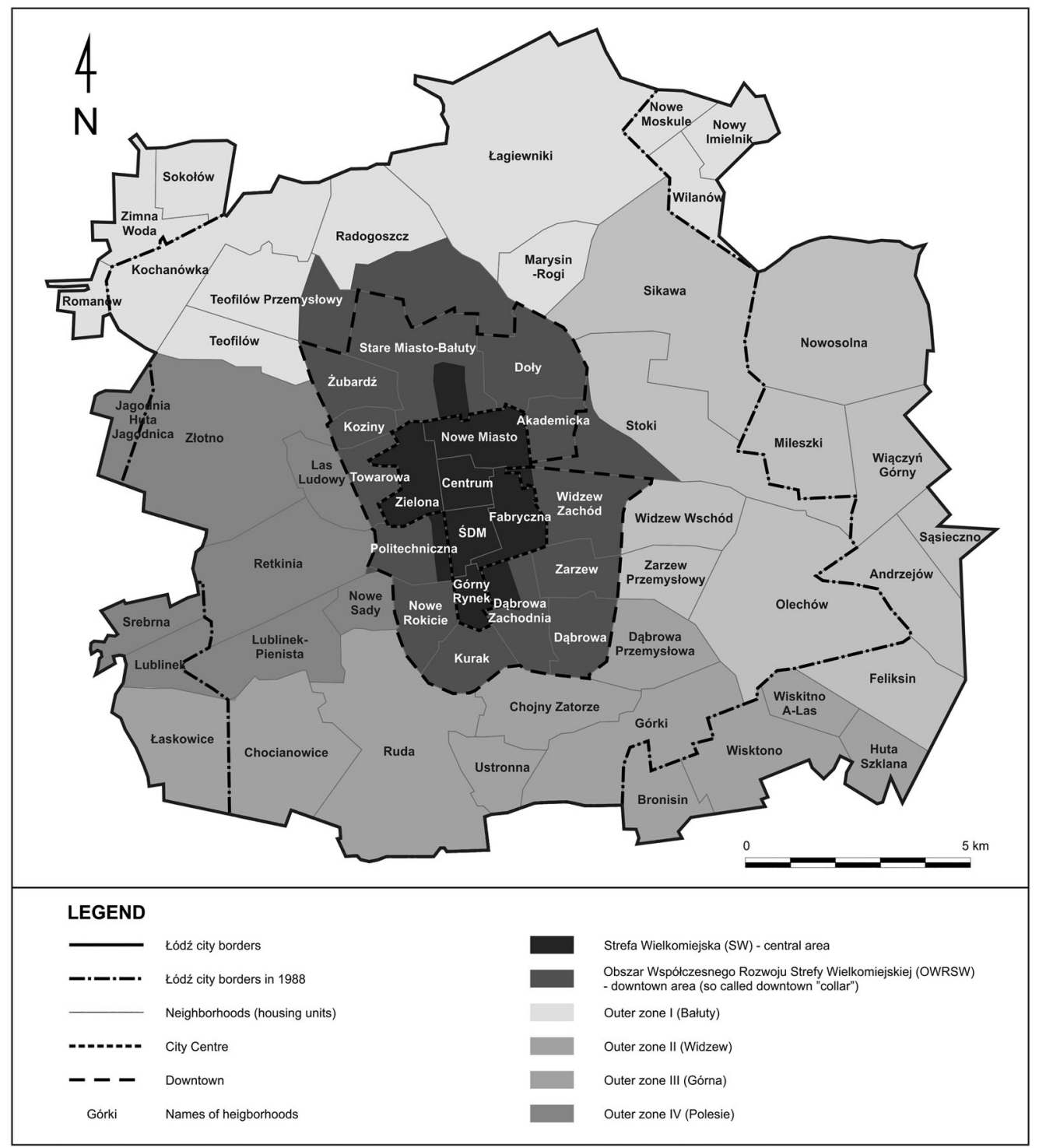

Figure 6. Administrative division of Łódź in 2017 (Source: authors' original work).

\section{Shrinkage of urban neighbourhoods in Łódź in 1988-2013: results of demographic and morphological analysis}

\section{Demographic changes}

Considering diverse dynamics of Łódź depopulation in the 1990s and in the early twenty-first century, examination of demographic changes in Łódź neighbourhoods was divided into two subperiods: 1988-2002 and 2003-2013. In the first one, the average annual depopulation dynamics was $-0.60 \%$ and was lower than the average reported for the entire analysed period1988-2013 $(-0.73 \%){ }^{8}$ For that period we identified 31 depopulating neighbourhoods, where the loss of inhabitants ranged between $-1.9 \%$ (in Ruda) to $-21.0 \%$ (in Centrum) and $-23.7 \%$ (in atypical Zarzew Przemystowy). ${ }^{9}$ Eleven neighbourhoods recorded population loss in the range $15-20 \%$, most of them situated in the downtown 'collar', predominantly in its north-western and southern regions. 
Neighbourhoods of Teofilów Przemysłowy and Park Ludowy in the closer outer zone of the city and SDM and Górny Rynek in the southern region of the historical centre (Figures 6 and 7(a)) were the only exceptions. Location of 12 units with depopulation rates between $10 \%$ and $15 \%$ was more diversified. Half of them were situated in the downtown 'collar', 4 in the closer outer zone, one in more distant outer zone, and one in the historical city centre (Figure 7(a)). It means depopulation tackled the inner city, most of it within the territorial borders of the nineteenth-century industrial Łódź built-up with old tenement houses. Depopulation was also reported for big blocks of post-war housing areas, mainly in: Koziny (-16.2\%), Żubardź (-16.0\%), Dąbrowa (-15.2\%), Nowe Rokicie (-14.4\%), Dąbrowa Zachodnia (-14.2\%), Teofilów (-13.5\%), Widzew Zachód (-12.3\%), Retkinia $(-12.0 \%)$, and much less in Widzew Wschód (-4.4\%) (Figure 7(a)). Over the same period, we could observe a clear increase in the population in neighbourhoods in more distant peripheral zone. We need to specifically mention the case of Olechów (+543\%), a unit embracing blocks of

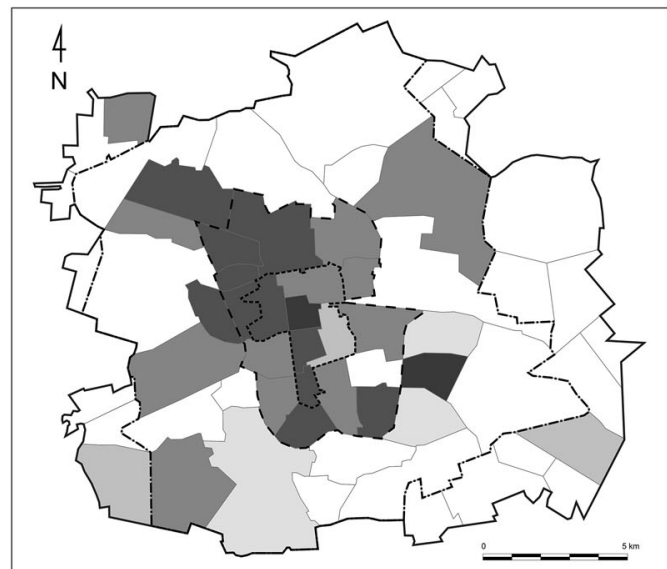

a) Population loss in Łódź neighbourhoods in 1988-2002

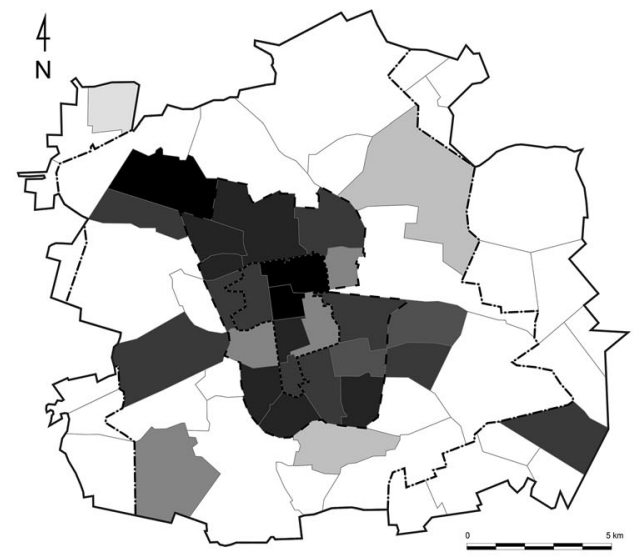

c) Population loss in Łódź neighbourhoods in 1988-2013

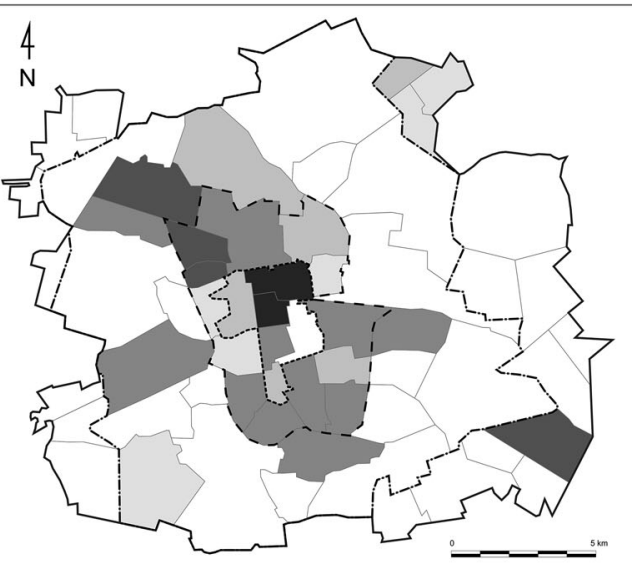

b) Population loss in Łódź neighbourhoods in 2003-2013

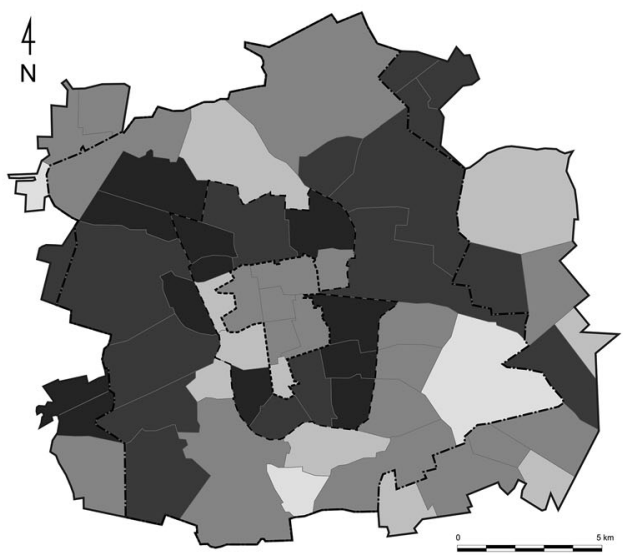

d) Population ratio in post working age in Łódź neighbourhoods in 2010

\begin{tabular}{|c|c|c|c|c|c|c|}
\hline LEGEND: maps a-d & LEGEND: maps a-c & LEGEND: map d & & & & \\
\hline _._. Łódź city borders in 1988 & Population lost: & Łódź population & & & & \\
\hline ...... City centre (Strefa Wielkomiejska - SW) & $x_{1}$ & $\begin{array}{l}\text { Population in post } \\
\text { working age in tódż }\end{array}$ & & & & \\
\hline $\begin{array}{ll}\text { - - Downtown "collar" (Obszar Współczesnego } \\
\text { Rozwoju Strefy Wielkomiejskiej - OWRSW) }\end{array}$ & & & 20 & 40 & 60 & 80 \\
\hline
\end{tabular}

Figure 7. Demographic changes in Łódź neighbourhoods in 1988-2013 (Source: authors' original work). 
flats and a greenfield investment project built at the turn of the 1980s and 1990s, which in the period covered by the study (but also currently) was considered an attractive area for developers as a potential location of multi- and single-family houses.

In the second analysed period, years 2003-2013, depopulation dynamics increased to $-0.85 \%$ annually. At the same time, the number of depopulating neighbourhoods dropped from 31 to 29 (Figure 7(b)). This period witnessed depopulation in almost the same neighbourhoods as in the years 1989-2002 situated in the historical city centre and in the downtown 'collar'. While percentage-wise the loss of inhabitants in the downtown 'collar' decreased, in the historical centre two opposite processes emerged. Depopulation of two units: Centrum (from $-21.0 \%$ to $-24.0 \%$ ) and Nowe Miasto (from $-14.4 \%$ to $-23.7 \%$ ), both recorded the highest population losses in the city in the period covered by the study, deepened. In SDM depopulation decreased from $-18.1 \%$ to $-14.0 \%$ and in Akademicka from $-10.2 \%$ to $-4.7 \%$. Large housing areas from the socialist era (with the exception of Olechów) and the neighbourhood of Radogoszcz built in the mid-1980s where population loss amounted to $-8.2 \%$ (compared to $+14.0 \%$ in $1988-2002$ ) continued losing inhabitants. Importantly, the trajectory of demographic growth in depopulating units of more distant peripheral zone changed, and population growth testified to advancing intra-city suburbanization. In this zone, only 3 units in the eastern part of the city were tackled with depopulation, mainly as a result of property expropriation and inconveniences connected with the construction of the ring road (A1 motorway).

As a result, for the entire period 1988-2013 we can identify 29 units with loss of population: from $-1.7 \%$ (Sokołów) to $-40.0 \%$ (Centrum). These units exhibit a clear spatial pattern (Figure $7(\mathrm{c})$ ) of concentric and wedge spatial layout. The deepest depopulation tackled the historical city centre, the northern and southern part of the downtown 'collar', and Teofilów Przemysłowy. Units in the historical centre are dominated with buildings built before the war, where standard of flats is often very poor, ${ }^{10}$ while in the downtown 'collar' there are large housing areas built in the early socialist period (until mid-1970s) by state-owned housing associations and offering flats that are substandard in comparison with those built in the late 1970s or in the 1980s. In the post-communist period, downtown areas have been omitted by private developers and new investments. Since mid-2000s the latter focused on post-industrial areas earmarked for regeneration. Hence a clear increase in population in the housing unit by the name of Fabryczna (Figures 6 and 7(a-c)), which attracted the biggest housing development projects in post-industrial areas in Łódź and, unlike other urban areas, have relatively clear-cut ownership structure. ${ }^{11}$ These were private investment projects which shows increasingly higher attractiveness of the city centre, especially in the context of limited supply of new dwellings in Łódź after 1990 (Figure 8) in the downtown area. At the same time, housing property prices in the private (developer's) market in Łódź were significantly lower than in other large cities in Poland (Table 6) which inhibited investment effort. Social and economic situation of people living in Łódź was on many fronts less favourable in the early 1990s than in other large cities in Poland (see Table 5); also the share of flats in the municipal housing stock is higher in Łódź than in other large cities in Poland. ${ }^{12}$

The loss of population over the years 1988-2013 visibly continued also in most large housing estates built during the communist period, in particular in older ones dating back to the 1960s and the 1970s. Notably, in 2010, that is between 30-40 years after they had been built and allocated to people, they were inhabited mostly by residents in retirement age and older (Figure $7(\mathrm{~d})$ ). These housing areas continue to be inhabited mainly by their first residents to whom flats were allocated under special state schemes. Currently, these flats are more and more often used by either their children or grandchildren (Szafrańska 2014). Often inherited flats are rented informally, which may also impact the size of statistical loss of residents. Analysis of the age-based structure of inhabitants of the neighbourhoods in Łódź highlights relatively lower rate of retired inhabitants in the historical city centre. Three reasons can be given to explain the situation. Firstly, gradual moving out of affluent people reaching the retirement age from the city centre. Secondly, early deaths of retired people in post-working age, ${ }^{13}$ and thirdly, the shrinkage of the housing stock in the historical centre, 


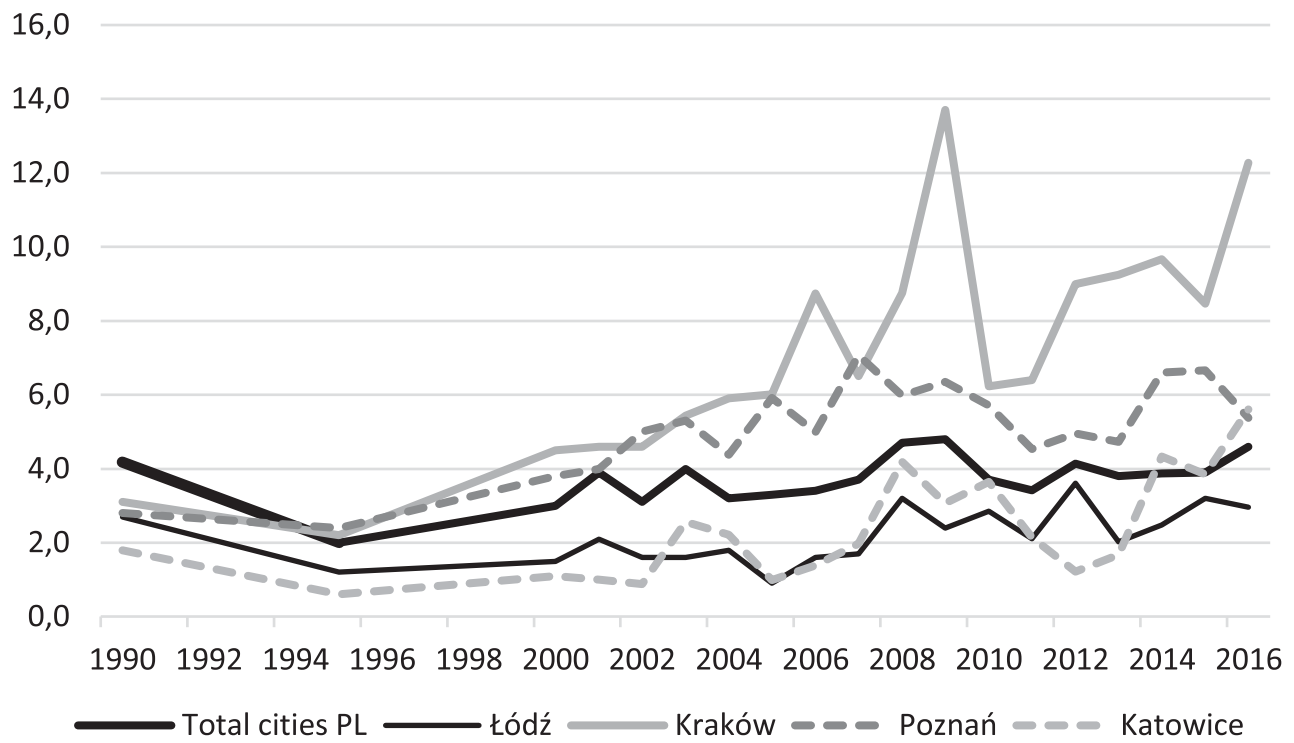

Figure 8. New dwellings per 1000 inhabitants in some Polish cities compared with all Polish cities during 1990-2016 (Source: Szafrańska, Coudroy de Lille, and Kazimierczak (2018)).

Table 6. Average transaction prices of flats at the end of 2006, 2010, and 2016 (gross price in PLN per $1 \mathrm{~m}^{2}$ )..

\begin{tabular}{|c|c|c|c|c|c|c|}
\hline \multirow{2}{*}{ City } & \multicolumn{3}{|c|}{ Primary market } & \multicolumn{3}{|c|}{ Secondary market } \\
\hline & 2006 & 2010 & 2016 & 2006 & 2010 & 2016 \\
\hline Łódź & 3215 & 5099 & 4850 & 2234 & 3910 & 3423 \\
\hline Warsaw & 6080 & 7500 & 7690 & 7214 & 7980 & 7231 \\
\hline Kraków & 7100 & 6930 & 6470 & 6148 & 6210 & 5951 \\
\hline Wrocław & 3650 & 5610 & 6163 & 4994 & 6050 & 5480 \\
\hline Poznań & 4910 & 6690 & 6285 & 4068 & 5110 & 5236 \\
\hline
\end{tabular}

Source: authors' compilation based on Annual reports of National Bank of Poland (Reports on the situation on residential and commercial real estate markets in Poland).

which has become an increasingly more interesting place to live for young people as a result of, inter alia, renovation schemes implemented by the Łódź City Council, i.e. the 'City of 102ant Houses Programme'. ${ }^{14}$ Dwellings in tenement houses refurbished mainly from private funds have become attractive to property investors as apartments for rent.

\section{Morphological changes: housing stock and urban fabric}

Examination of morphological transformations in the neighbourhoods of Łódź was much more difficult due to a variety of sources of data, their scope and periods, for which data have been collected. Hence, it was difficult to identify two periods of morphological transformations analogous to demographic changes described above.

For the years 1988-2013 we found 9 neighbourhoods, which reported losses in the dwelling stock: atypical unit of Zarzew Przemystowy $(-50.0 \%)^{15}$ and Feliksin $(-14.4 \%)$, Górny Rynek (-7.7\%), Kurak (-3.1\%), Teofilów Przemysłowy (-3.1\%), Nowe Rokicie (-1.4\%), Nowe Miasto (-0.6\%), Koziny (-0.6\%), and Stare Miasto-Bałuty (-0.1\%) (Figures 6 and 9(a)). However, only in Górny Rynek the loss of dwellings was continuous and long-term while other units exhibited recent resurgence in the dwelling stock in the years 2002-2013. ${ }^{16}$ Remarkably, all of these 9 above-mentioned units were depopulating neighbourhoods over the years 1988-2013. Yet, the dominant type of housing differed across them: from the pre-war tenement houses (Nowe Miasto and Górny Rynek) 
through single-family houses (Feliksin) up to blocks of flats from the communist times (the remaining units). There was no regularity indicative of the loss of dwellings in any particular types of buildings. Space-wise we can identify two areas where dwelling losses have concentrated: in the northern and southwestern part of the historical centre and in the downtown 'collar'. Over the same time, the biggest increase in dwelling stock was reported in units located in more distant peripheral zone of Łódź (Figure 9(a)). These new residential areas are populated by affluent individuals, which is reflected in spatial distribution of residential mansions. According to Dzieciuchowicz and Groeger (2016), no new residential complexes were constructed in the inner city of Łódź from 1990-2014, whereas in the outer zones, 22 such complexes were built only in 2008-2009.

Particularly intensive loss of dwellings in Łódź occurred in the years 1988-2002, which is confirmed by the Census in 2002. Over this period the problem tackled 18 units, i.e. over twice as many as in the years 1988-2013. The problem covered all of the historical core of the city (6 neighbourhoods), 10 out of 13 units in the downtown 'collar' and 3 units in the closer outer zone (Figure 9 (b)). With the exception of Dabrowa Przemysłowa and Park Ludowy, the remaining 17 units were depopulating over that time. Simultaneously, almost the same neighbourhoods recorded the loss of housing stock in the years 1988-2002 (Figure 9(b)), which suggests that the loss of dwellings did not result from, e.g. merging adjacent flats. ${ }^{17}$ Two units witnessed structural changes in the housing stock. In Nowe Sady the loss of dwellings was accompanied by increases in the dwelling stock, meaning new multi-family houses were built. In Dąbrowa Przemysłowa housing stock increase was accompanied by the decrease of the dwelling stock, meaning the share of private houses grew in the housing stock of this unit (Figures 6 and 9(b)).

Analysis of data from the Census of 2002 also helped us learn about the age of the housing stock that suffered the biggest losses in the years 1988-2002 broken down by Łódź neighbourhoods. In units, which suffered from the loss of housing stock the loss hit mainly buildings erected before 1918 (in Dąbrowa Zachodnia, Doły, Fabryczna, Górny Rynek, Nowe Miasto, Nowe Sady, Stare Miasto-Bałuty, and Zielona). Buildings from the period 1918-1944 suffered slightly less (in Centrum, Koziny, Kurak, Nowe Rokicie, Teofilów Przemysłowy, and Towarowa). In Park Ludowy and Politechniczna losses hurt the housing stock from 1945 to 1970, while in SDM and in Widzew Zachód houses built after 1970 suffered the most. Taking the city as a whole, over the years 1988-2002 losses prevailed in the housing stock dated back to before 1918 (29 units) and from the period 1918-1944 (25 units). The loss in housing stock in the city and in individual development zones in Łódź covered mostly buildings constructed before WWII offering dwellings of the lowest standard (Table 7).

Gradual loss of the oldest housing stock, especially the substandard one, looks like a 'natural' process in the growth of a city. It is also explained by a wide range of theoretical concepts, such as, e.g. the concept of burgage cycle (Conzen 1962), the concept of normal (natural) life-span (Harris 1999; James 2012; Thomsen and van der Flier 2009), and the theory of obsolescence (Thomsen and van der Flier 2011). Elimination of old and degraded housing stock may also be part of regeneration as, e.g. an element of the recovery process as a response to 'modernization gap' (Harvey 1989a), implementation (large-scale) of urban development projects (Kazimierczak and Kosmowski 2017; Lehrer and Laidley 2008; Orueta and Fainstein 2008; Turok 1992) or state-led gentrification (Betancur 2002; Smith and DeFilippis 1999; Weber et al. 2006). However, what is important to depopulating cities is a phenomenon consisting in total absence or very few new housing developments in areas, where depopulation is the most acute as observed, inter alia, by Grossmann et al. (2014). As a result,

Table 7. Basic technical and sanitary installations available in flats in development zones in Łódź in 2002 (in \%).

\begin{tabular}{lcccc}
\hline Installation by type & Łódź & Łódź historical core & Łódź downtown 'collar' & Łódź outer zones \\
\hline Bathroom & 79.8 & 64.8 & 81.3 & 81.4 \\
Hot water & 78.7 & 64.7 & 81.6 & 79.7 \\
Gas & 52.5 & 72.4 & 79.9 & 41.2 \\
\hline
\end{tabular}

Source: authors' compilation based on National Census 2002. 


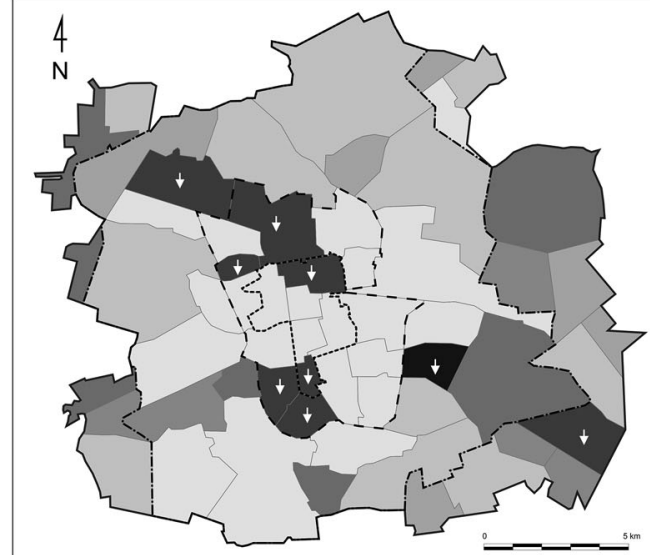

a) Dwellings change in Łódź neighbourhoods in 1988-2013

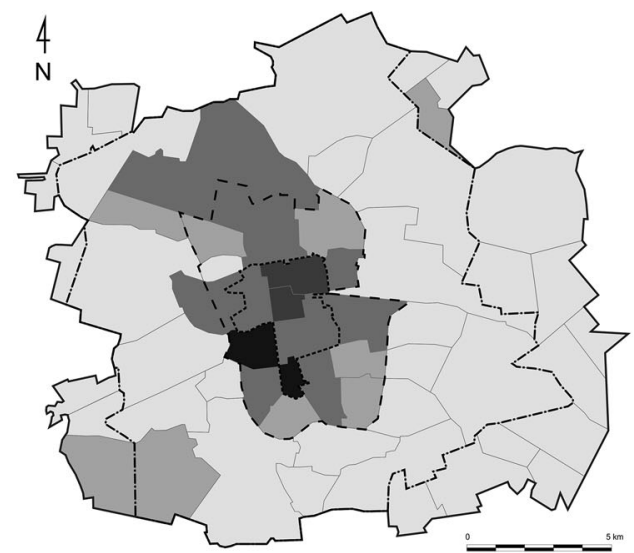

c) Urban fabric change in Łódź neighbourhoods in 1994-2009

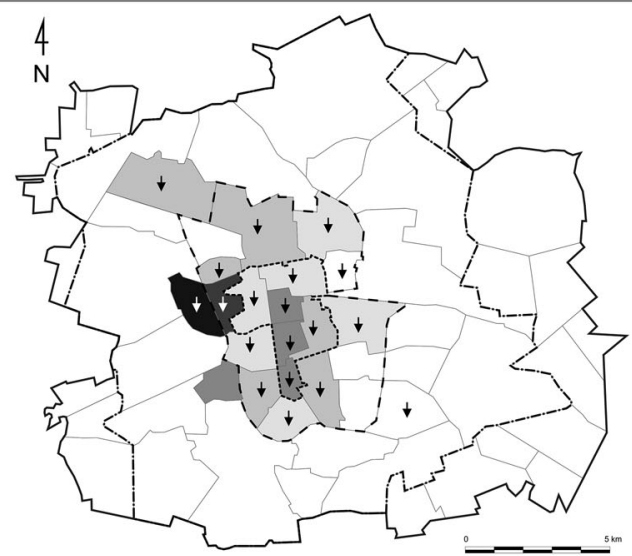

b) Dwellings and residential buildings change in Łódź neighbourhoods in 1988-2002

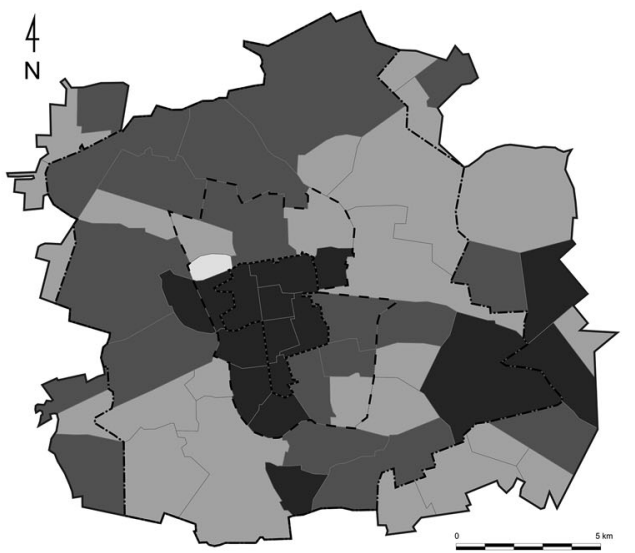

d) Urban fabric change in Łódź neighbourhoods in 2009-2011

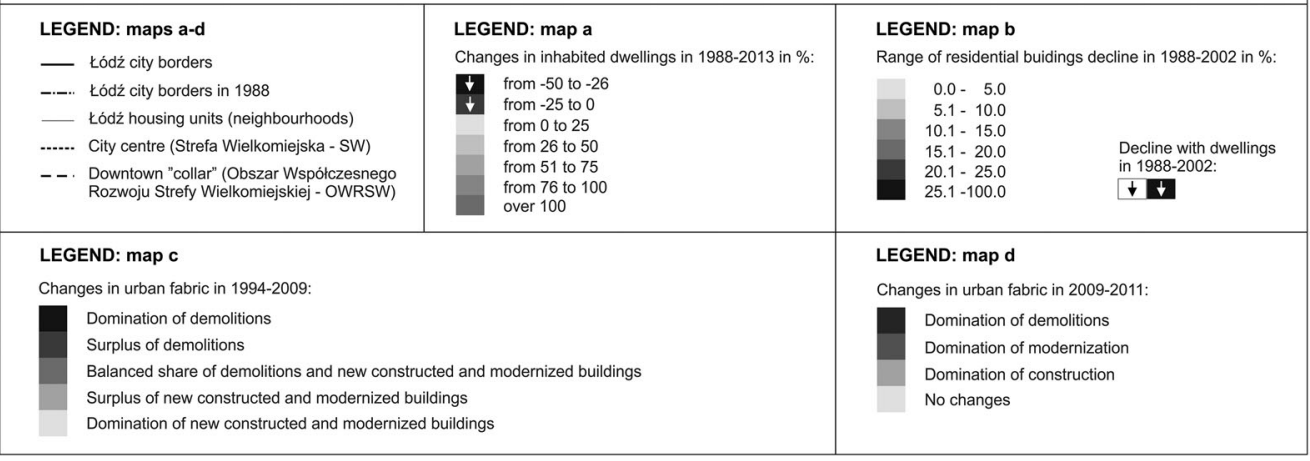

Figure 9. Morphological changes in Łódź neighbourhoods in 1988-2013 (Source: authors' original work).

old housing stock is not replaced with the new one and the crisis area falls into the 'spiral of multifaceted shrinkage'. Relatively low investment attractiveness of the historical core and the downtown 'collar' of Łódź compared to the peripheral zones is confirmed by the presence of non-developed plots and vacant dwellings in the central area of the city. Furthermore, the Census in 2002 showed there were 2000 flats in Łódź that had to be demolished due to their poor technical condition. According to the investigation conducted by the City Council in 2016, there are 500 inhabited 
and vacant tenement houses in the historical core and in the downtown 'collar' area. These houses will be demolished by 2020 as part of the urban regeneration programmes implemented in Łódź since 2014. In the case of Łódź the loss of dwellings stock after 1988, in particular in the historical city centre and in the downtown 'collar', was also caused by commercialization of the housing sector and adapting some of its stock to metropolitan functions. The process covered predominantly areas adjacent to the main commercial street in Łódź - Piotrkowska street. Advancing succession of functions testifies to the advancing economic transformation in the central area of Łódź and metropolization of the city. As claimed by Sýkora (2009) the process is typical of post-socialist cities in CEE.

Analysis of changes in urban housing stock performed for the period 1994-2011 indicates the domination of demolition effort in the historical core and in the downtown 'collar' over modernization of the urban fabric, including regeneration and building new establishments also on cleared plots (Figure 9(c-d)). Losses in the housing stock in Łódź were observed in the dwelling stock (Figure $9(\mathrm{a}-\mathrm{b})$ ), as well as in service facilities, service and housing premises, and in post-factory infrastructure. Since the early 1990 s ca. $50 \%$ of industrial premises in privately owned (privatized) plots in Łódź got demolished, in particular in the historical core and in the downtown 'collar'(Kaczmarek et al. 2018). Although brownfields were potentially attractive investment areas because of their size and central location in the city (Kazimierczak 2014a), only few of them have got regenerated or experienced any manifestation of investment effort in the years 1988-2013.

In accordance with the creative destruction concept, ${ }^{18}$ urban fabric demolition comes as a natural transformation in social and economic development leading to desirable changes in spatial and functional structure and urban landscape that meet the needs of contemporary users of the city. In postindustrial and post-socialist cities where urban space management follows an extensive pattern, increasing the density of the urban fabric by ensuring the prevalence of construction over deconstruction of buildings or, at least, by balancing both types of effort is very much welcome. Continuous and significant loss of the urban fabric means unsatisfactory succession and is indicative of social and economic distress of the city. In the light of the above, the case of Łódź, in particular of its central area (Figure 9(c-d)) where destruction (degradation and deconstruction) prevailed, illustrates social and economic distress. The latter can be treated as a structural crisis which combined with depopulation is typical of shrinking cities (areas).

\section{Actually shrinking neighbourhoods in Łódź: comparison of shrinking neighbourhoods in demographic and morphological dimensions with run-down and urban areas}

Conducted studies have provided evidence that in Łódź 29 neighbourhoods got depopulated while 32 reported population increases over the period 1988-2013 (Figure 10(a)). Moreover, analysis of demographic and morphological data showed that 29 depopulating neighbourhoods represent different development trajectories (Figure 10(b-c)). Among them we identified 1 neighbourhood (Zarzew Przemysłowy) where no changes in the urban fabric were reported (stagnantion) and 11 neighbourhoods where urban fabric, including the housing stock, increased. These neighbourhoods are located in the closer outer zone in which there are mostly blocks of flats dating back to the communist times (Akademicka, Chojny Zatorze, Dąbrowa, Retkinia, Teofilów, Widzew Wschód, Zarzew, $\dot{Z} u b a r d z$ ) and single-family houses (Stoki) as well as in the distant outer zone (Chocianowice, Sokołów). The remaining 17 neighbourhoods are actually shrinking neighbourhoods (areas) of Łódź in which we can observe simultaneous outflow of residents and the loss of urban fabric (also housing stock). This group includes all neighbourhoods in the historical centre (Centrum, Fabryczna, Górny Rynek, Nowe Miasto, SDM, Zielona) 9 out of 13 neigbourhoods in the downtown 'collar' (Dąbrowa Zachodnia, Doły, Koziny, Kurak, Nowe Rokicie, Politechniczna, Stare Miasto-Bałuty, Towarowa, Widzew Zachód) and 1 neighbourhood in the closer peripheral zone built-up mostly with multifamily from the state-socialist era (Teofilów Przemysłowy) and 1 neigbourhood in the more distant peripheral zone where single-family houses dominate the landscape (Feliksin). 


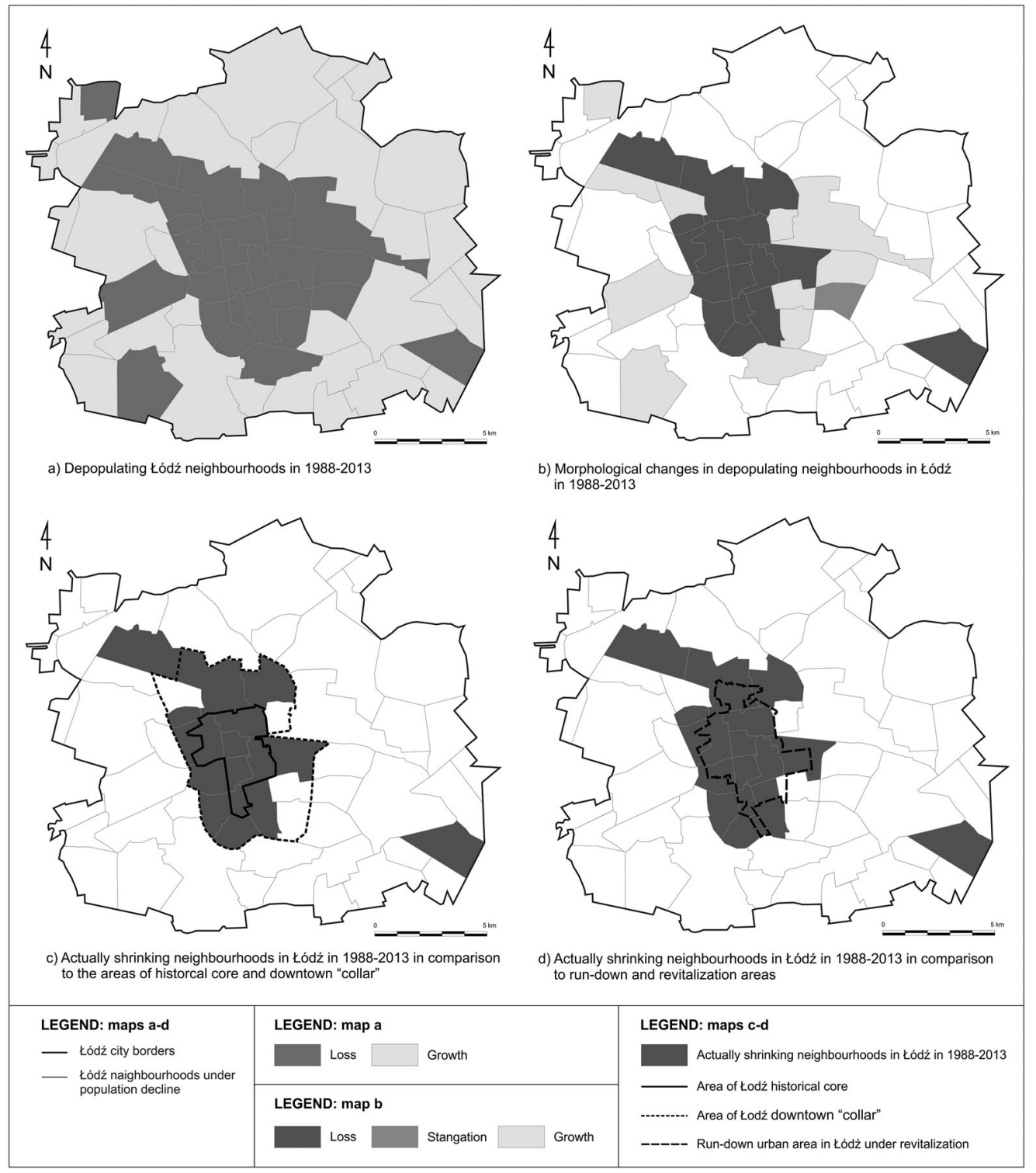

Figure 10. Trajectories of neighbourhoods development and categories of shrinking neighbourhoods in Łódź in 1988-2013 (Source: authors' original work).

Conducted studies revealed that the scope of the 17 actually shrinking neighbourhoods in Łódź overlaps with the scope of degraded area that requires regeneration effort which was identified in Łódź Municipal Regeneration Programme 2026+. ${ }^{19}$ The degraded area covers 1.783 ha representing $6.1 \%$ of the total area of Łódź (Figure 10(d)) and inhabited by 152,292 people, i.e. $22.8 \%$ of all city dwellers. ${ }^{20}$ We need to stress that the analysis carried out by the Łódź City Council and used as the basis for delimitation of the degraded area did not account for the changes in population, urban fabric, or housing stock i.e. categories deployed in the study to identify the actually shrinking urban areas in Łódź. This is the area of degraded housing stock tackled with negative social and economic developments in which over the period 19882013 we could observe progressing loss in population and in the housing stock, including the 
dwelling stock. That is why we should refer to it as an area suffering from multifaceted structural crisis typical of shrinking cities. In order to recover the historical centre and the downtown 'collar' of Łódź since the early twenty-first-century city authorities have been carrying out subsequent programmes, also regeneration programmes.

These municipal programmes have been carried out with mixed efficiency. Undoubtedly, they have improved the quality of public space, mainly in the historical city centre with the main Piotrkowska street and helped modernize more than 100 tenement houses in the city centre. These efforts will be continued in the historical centre of Łódź until 2020 within the framework of regeneration programme co-financed with the EU funds. Its direct goal is to revive the economic centre of the city while indirectly it intends to encourage young people living in Łódź to move into the city centre, also by offering the above urban programmes. Since 2012 the historical city centre (Centrum, Fabryczna, and Nowe Miasto) has been the theatre of one of the biggest European mega-projects in urban regeneration called Nowe Centrum Łodzi (NCŁ) [New Centre of Łódź]. Together with a new underground railway station, the centre of the city and post-railway areas (extending over 100 ha in total) host office buildings and cultural functions. New apartments are also constructed meaning in several years to come there will be more people living in these neighbourhoods, perhaps at the cost of other neighbourhoods, which will lose some of their residents. However, the implementation of the NCŁ project and the increase in the population do not necessarily mean comprehensive revival of the shrinking centre of Łódź as the process will be limited to its part covered with costly regeneration programmes.

\section{Conclusions and discussion}

Łódź is a city which lost over 18\% of its population over the period 1988-2016 and that is why it is considered a shrinking city (e.g. Turok and Mykhnenko 2007, 2008; Ogrodowczyk and Marcińczak 2014). Studies at the intra-urban scale conducted for the years 1988-2013 have revealed a more detailed picture of the process. Based on the analysis of changes in the population in 61 neighbourhoods in Łódź we demonstrated that depopulation took place in only 29 of them while the remaining 32 neighbourhoods reported population increases. Importantly, depopulation scale of 29 neigbourhoods significantly exceeded population increases in these other 32 neigbourhoods. This explains why in absolute terms Łódź is considered as shrinking city as a whole, despite the fact only particular parts of the city are affected by high depopulation and other negative consequences of inhabitants' loss. Moreover, we found out that depopulating neighbourhoods are located in the oldest parts of the city, that is in its historical centre and in the so-called downtown 'collar'. In the light of the studies, we have shown that poor quality of the housing stock is one of the reasons of intensive depopulation in central areas of the city. In accordance with theoretical assumptions adopted for the study that refer to the Klassen (1988) concept of mismatch between urban and social sub-systems, permanent loss in dwelling stock, dwelling-service facilities, service establishments and post-industrial buildings in neighbourhoods in the city centre of Łódź in the years 1988-2013 not compensated with new investment projects is also indicative of social and economic distress experienced in this zone. Our studies also demonstrate that depopulation and loss in the housing stock went on hand in hand in 17 neighbourhoods in the city centre of Łódź and in accordance with the holistic model of shrinkage (Haase et al. 2014) these neighbourhoods should be referred to as actually shrinking urban areas. They were identified by using an original demographic and morphological method. The correctness of adopted morphological assumptions and the efficiency of the method applied to identify shrinking areas in the city can be confirmed by the fact that 17 neighbourhoods in Łódź identified as actually shrinking overlap with the degraded area calling for regeneration specified in Łódź Municipal Regeneration Programme 2026+ based on parameters other than demography and morphology. Studies conducted in Łódź justify why we need studies at the intra-urban scale since this level of analysis provides framework for proper identification and interpretation of spatial consequences of shrinkage. 
Years between 1988 and 2013 also witnessed population loss in housing districts from the socialist times even though such districts are often seen as more attractive to live than the city centre mainly due to higher standard and more functional flats as well as 'better' social environment and the presence of green areas. Moreover, the situation has not changed despite advancing regeneration effort in the city centre. Unlike the city centre and housing districts with blocks of flats, neighbourhoods in the outer zone (outside of the large housing estates) became development areas of the city as a result of inner-urban suburbanization as indicated by increases in population and in the housing stock. The process leads to urban sprawl but also to the so-called doughnut effect considering intensive depopulation of the Łódź city centre. Both processes take place at demographic and morphological levels, they intertwine and permeate providing arguments for identification of urban shrinkage. Causes and effects of such a process cannot be unambiguously identified which is confirmed by, e.g. Grossmann et al. (2008) and Haase et al. (2014). In Łódź, like in other post-socialist cities in CEE region, shrinkage became a vicious circle of mutually penetrating (and reinforcing) processes and factors caused by the systemic transformation which triggered the 'decline' of the most sensitive area of the city. In Łódź, similarly to many other nineteenth-century post-industrial cities, the area covers the city centre with the oldest and the most degraded dwelling stock inhabited predominantly by vulnerable people the most exposed to negative changes in economy that accompanied systemic transformation. From this perspective, urban shrinkage experienced in Łódź, in fact only with its central part, is connected with structural crisis, in which depopulation clearly links with economic and spatial decline as confirmed by the opinion of, inter alia, (Martinez-Fernandez et al. 2016) about strong interdependence of these two processes.

At theoretical and methodological level, the case study of Łódź particularly clearly fits the perforated city concept (Florentin 2016) based on intra-urban scale analysis. Its goal is also to identify actually shrinking neighbourhoods using demographic and other complementary data, not necessarily morphological ones. Theoretical and methodological perspective proposed in this paper broadens current debate on the conceptualization of urban shrinkage taking account of new, more applicationoriented approaches reflected in the concept of 'shrinking smart' (Pallagst, Fleschurz, and Said 2017) and 'smart decline' (Hollander and Nemeth 2011). No doubt, the CEE perspective is relevant here (Sjöberg 2014) as this is the part of Europe experiencing very intense and closely related processes of depopulation and degradation of urban areas. As claimed by Blanco et al. 2009, structural changes in depopulating cities provoked by multifaceted decline seriously impede their coming back to the previous growth path, i.e. to restore increasing population, jobs, dwellings, etc. It is especially difficult in the context of neoliberal paradigm of inter-ubran competition for investment and residents (Hospers 2011). Nevertheless, it is worth noting that in contemporary Łódź, similarly to many other post-socialist cities in the CEECs which inherited the so-called 'dwelling shortage' after the times of state-socialism (Szafrańska, Coudroy de Lille, and Kazimierczak 2018) which was reflected in overcrowded flats in old often degraded housing stock in the city centre as well as in large housing districts filled with blocks of flats, depopulation may also be seen as a positive or even desirable process. Although such an assessment of urban shrinkage may be controversial, which is why it is rarely articulated in literature, it seems that in the case of Łódź it can be considered justified.

\section{Notes}

1. The international research project 'Cities Regrowing Smaller - Fostering Knowledge on Regeneration Strategies in Shrinking Cities across Europe' (CIRES) was implemented under the COST Action TU0803 with the participation of scholars representing 26 countries in Europe.

2. Credibility of demographic data is discussed in great detail in the section Data sources.

3. The assumption is clearly linked with the idea of accumulation of capital and its spatial-temporal circulation (see section 2).

4. In 1865 Łódź had 40,000 residents and was the fifth largest city in the then Poland while in 1880 with 253,000 residents it became the second largest city and maintained this position until 1997. Because of its development dynamics Łódź is also compared to Manchester (it is even called 'Polish Manchester') even though in the period 
1825-1900 its development rate significantly exceeded that of its English counterpart. While in this period the population of Łódź increased by 334 times from 940 to 314,000 (Jakóbczyk-Gryszkiewicz 1997), in Manchester population grew 8 times, from 84,020 in 1801 to 714,333 in 1901 (Lever and Young 1997).

5. In accordance with the definition of a shrinking city it is a city where the loss of population amounts to minimum $0.15 \%$ annually over at least 5 years (see section 1 ).

6. For comparison, depopulation in Donetsk, Ukraine, over the period 1991-2013 reached 15\% while that of Makiivka, Ukraine, described by Haase, Rink, and Grossmann (2016) - 22\% but this is a medium-sized city by European standards.

7. In the 1990 s technical outlays on the maintenance of municipal dwelling stock in cities with population exceeding 100,000 residents on average amounted to $0.79 \mathrm{PLN} / \mathrm{m}^{2}$ while in Łódź it was $0.54 \mathrm{PLN} / \mathrm{m}^{2}$, i.e., $68 \%$ of the country average (Housing economy ..., p. 69).

8. Over the years 1988-2016 annual average depopulation dynamics was $-0.75 \%$.

9. Zarzew Przemysłowy, similarly to other intra-city industrial districts (Dąrowa Przemysłowa and Nowe Sady) and leisure areas (Park Ludowy) were especially sensitive to changes in their population as they were rather scarcely populated (from 242 to 772 people in 2013). Teofilów Przemysłowy inhabited by 1310 residents in 2013 is an exceptional case.

10. Data from national census in 2002 showed that $27 \%$ of housing resources in Lodz available in 2002 dated back from before 1944. Buildings concentrated in the historical city centre and in the downtown 'collar'. The Census also demonstrated that these tenement houses offered flats of the lowest standard in the city, 50\% of them without central heating, $12 \%$ without WC, and $30 \%$ were not connected to the main sewerage system.

11. In the state-socialism age in Łódź industrial areas and premises were nationalized while other land and property in the city, previously owned mainly by Jews or Germans were taken over by state administration. Few tenement houses owned by the Poles formally remained private but in practice they were discretionally managed by state administration. After the systemic transformation in the 1990s this property first became municipal (taken over by municipal authorities) and then partly privatized (sold to new owners) or reprivatized, which, however, was not always possible since there were often no heirs. This is also why ownership of many plots and property in the city centre in Łódź remains unclear.

12. In 2002 the share of municipal housing stock in Łódź in the total number of flats was as high as $23.4 \%$ and dropped to $12.9 \%$ in 2016 . The share in 2016 was still higher than in Warsaw $-8.6 \%$, Kraków - 4.3\%, Wrocław - $11.7 \%$, and Poznań - 4.9\%.

13. These are often people who moved to cities following WW II to work in intensely growing textile industry. Due to the lack of sufficient housing stock these people were allocated flats in the downtown, at that time stateowned. These flats were further repartitioned often into single-room flats with shared toilet at each floor.

14. Polish: 'Mia100 Kamienic'.

15. Very high loss rate results from very limited pool thereof in the unit dominated with the industrial function and premises.

16. In the period 2002-2013 the loss of dwellings in the historical core of the city was reported only for Górny Rynek. In closer and more distant peripheral zones dwellings decline occurred only in Zarzew Przemysłowy, Wiączyń Górny, and Feliksin.

17. In the socialist era, due to the shortage of dwellings, large multi-bedroom apartments in old tenement buildings were repartitioned and in parts allocated to different families. The free of charge allocation schemes were fully lawful in the Polish People's Republic. Repartitions of flats often led to solutions, such as shared toilets outside of these flats in the so-called shared spaces. Nowadays, the apartments are gradually merged back, which, however, due to little dynamics does not importantly impact the overall number of dwellings in Łódź.

18. The concept of creative destruction was developed in economic sciences by Nietzsche, Hegel and Schumpeter, and adapted for social and economic geography by Harvey (1989b, 1990).

19. It is a strategic document used by the Łódź City Council as a basis for planning and implementation of regeneration programmes financed from own resources of the city (municipality), government and the EU funds.

20. For the sake of comparison, a degraded area in southern part of Manchester city centre where regeneration was carried out in the years $1988-1996$ extended across 165 ha, i.e. $0.014 \%$ of the city (Kazimierczak 2014b).

\section{Acknowledgements}

The author thanks two anonymous reviewers and prof. Sylwia Kaczmarek for suggestions that helped improve this paper.

\section{Disclosure statement}

No potential conflict of interest was reported by the authors. 


\section{Funding}

This work was supported by National Science Centre Poland [grant number DEC-2014/15/B/HS4/01940]; Ministry of Science and Higher Education Republic of Poland under Grants for Young Scholars [grant number WNG UL B1711700001571.02].

\section{ORCID}

Jarosław Kazimierczak (D) http://orcid.org/0000-0001-5547-7269

Ewa Szafrańska (D) http://orcid.org/0000-0002-6779-3100

\section{References}

Aiello, A., R. Ardone, and M. Scopelliti. 2010. "Neighborhood Planning Improvement: Physical Attributes, Cognitive and Affective Evaluation and Activities in two Neighborhoods in Rome." Evaluation and Program Planning 33 (3): 264-275.

Audirac, I., E. Cunningham-Sabot, and S. Fol. 2012. "Declining Suburbs in Europe and Latin America." International Journal of Urban and Regional Research 36: 226-244.

Beauregard, R. 2009. "Urban Population Loss in Historical Perspective: United States, 1820-2000." Environment and Planning A 41: 514-528.

Bernt, M. 2009. "Partnerships for Demolition: The Governance of Urban Renewal in East German Shrinking Cities." International Journal of Urban and Regional Research 33 (3): 754-769.

Bernt, M., C. Cortese, C. Couch, M. Cocks, K. Grossmann, A. Haase, and R. Krzysztofik. 2014. "How Does(n't) Urban Shrinkage get Onto the Agenda? Experiences from Leipzig, Liverpool, Genoa, and Bytom." International Journal for Urban and Regional Research 38 (5): 1749-1766.

Betancur, J. J. 2002. "The Politics of Gentrification: The Case of West Town in Chicago." Urban Affairs Review 17: $262-$ 331.

Blanco, H., M. Alberti, R. Olshansky, S. Chang, S. Wheeler, J. Randolph, B. London, et al. 2009. "Shaken, Shrinking, Hot, Impoverished and Informal: Emerging Research Agendas in Planning." Progress in Planning 72 (4): 195-250.

Brainerd, E. 2012. "The Demographic Transformation of Post-Socialist Countries: Causes, Consequences, and Questions." In Economies in Transition. Studies in Development Economics and Policy, edited by G. Roland, 5783. London: Palgrave Macmillan.

Cirtautas, M. 2013. "Urban Sprawl of Major Cities in the Baltic States." Architecture and Planning 7: 72-79.

City Spatial Development Strategy until 2020+. [Strategia przestrzennego rozwoju Łodzi 2020+, załącznik do uchwały nr LV/1146/13 Rady Miejskiej w Łodzi z dnia 16 stycznia 2013 r.], Łódź: Łódź City Council.

Conditions and Directions of Spatial Development of Łódź. [Studium Uwarunkowań i Kierunków Zagospodarowania Przestrzennego Łodzi z 2010 roku]. Łódź: Łódź City Council.

Conzen, M. R. G. 1962. "The Plan Analysis of an English City Centre." In Proceedings of the IGU Symposium in Urban Geography, edited by K. Norborg, Vol. 24, 384-414. Lund: Gleerup, Lund Studies of Geography.

Couch, C., and M. Cocks. 2011. "Underrated Localism in Urban Regeneration: The Case of Liverpool, a Shrinking City." Journal of Urban Regeneration and Renewal 4: 279-292.

Couch, C., M. Cocks, M. Bernt, K. Grossmann, A. Haase, and D. Rink. 2012. "Shrinking Cities in Europe." Town \& Country Planning 81 (6): 264-270.

Couch, C., J. Karecha, H. Nuissl, and D. Rink. 2005. "Decline and Sprawl: An Evolving Type of Urban Development Observed in Liverpool and Leipzig." European Planning Studies 13: 117-136.

Cunningham-Sabot, E., and S. Fol, et al. 2009. "Shrinking Cities in France and Great Britain: A Silent Process?" In The Future of Shrinking Cities - Problems, Patterns and Strategies of Urban Transformation in a Global Context, edited by K. Pallagst, 17-27. Berkeley: Center for Global Metropolitan Studies, Institute of Urban and Regional Development, and the Shrinking Cities International Research Networks, University of California.

Dewar, M., and J. M. Thomas. eds. 2013. The City After Abandonment. Philadelphia: University of Pennsylvania Press.

Łódź Housing Policy 2020+. [Polityka Mieszkaniowa Łodzi $2020+$ ]. Łódź: Łódź City Council.

Łódź Local Regeneration Programme in 2007-2013. [Lokalny Program Rewitalizacji Łodzi w latach 2007-2013]. Łódź: Łódź City Council.

Łódź Municipal Regeneration Programme 2026+. [Gminnym Programie Rewitalizacji Łodzi 2026 + ]. Łódź: Łódź City Council.

Dzieciuchowicz, J., and L. Groeger. 2016. Nowa przestrzeń mieszkaniowa: Lofty i rezydencje $w$ Łodzi [New Housing Space: Lofts and Mansions in Łódź]. Łódź: Łódź University Press.

Florentin, D. 2016. “The "Perforated City:” Leipzig's Model of Urban Shrinkage Management." Berkeley Planning Journal 23 (1): 83-101. 
Fol, S. 2012. "Urban Shrinkage and Socio-Spatial Disparities: Are the Remedies Worse Than the Disease?" Built Environment 38: 259-275.

Geshkov, M. 2015. "Urban Sprawl in Eastern Europe. The Sofia City Example.” Economic Alternatives 2: $101-116$.

Grossmann, K., A. Haase, T. Arndt, C. Cortese, P. Rumpel, D. Rink, O. Slach, I. Ticha, and A. Violante. 2014. "How Urban Shrinkage Impacts on Patterns of Socio-Spatial Segregation: The Cases of Leipzig, Ostrava, and Genoa." In Urban Ills: Post Recession Complexities to Urban Living in Global Contexts, edited by C. C. Yeakey, V. S. Thompson, and A. Wells, 241-267. New York: Lexington Books.

Grossmann, K., A. Haase, D. Rink, and A. Steinführer. 2008. "Urban Shrinkage in East Central Europe; Benefits and Limits of a Cross-National Transfer of Research Approaches.” In Declining Cities, edited by M. Nowak and M. Nowosielski, 77-99. Poznań: Instytut Zachodni, Poznań.

Haase, A., M. Bernt, K. Grossmann, V. Mykhnenko, and D. Rink. 2016. "Varieties of Shrinkage in European Cities." European Urban and Regional Studies 23 (1): 86-102.

Haase, A., D. Rink, and K. Grossmann. 2016. "Shrinking Cities in Post-Socialist Europe: What can We Learn from Their Analysis for Theory Building Today?” Geografiska Annaler: Series B, Human Geography 98 (4): $305-319$.

Haase, A., D. Rink, K. Grossmann, M. Bernt, and V. Mykhnenko. 2014. "Conceptualizing Urban Shrinkage." Environment Planning 46 (7): 1519-1534.

Haase, A., A. Vaishar, and G. Węcławowicz. 2011. “The Post-Socialist Condition and Beyond: Framing and Explaning Urban Change in East Central Europe." In Residential Change and Demographic Challange. The Inner City of East Central Europe in the 21st Century, edited by A. Haase, A. Steinführer, S. Kabisch, A. Grossmann, and R. Hall, 6383. Burlington: Ashgate.

Harris, N. 1999. Building Lives: Constructing Rites and Passages. Chelsea: Yale University Press.

Harvey, D. 1989a. The Urban Experience. Baltimore: Johns Hopkins University Press.

Harvey, D. 1989b. "From Managerialism to Entrepreneurialism: The Transformation in Urban Governance in Late Capitalism.” Geografiska Annaler B, Human Geography 71 (1): 3-17.

Harvey, D. 1990. "Between Space and Time: Reflections on the Geographical Imagination.” Annals of the Association of American Geographers 80 (3): 418-434.

Historia Polski w liczbach. Ludność. Terytorium. [History of Poland in numbers. Population. Territory]. 1994. Warszawa: Główny Urząd Statystyczny.

Hoekveld, J. 2012. “Time-Space Relations and the Differences Between Shrinking Regions.” Built Environment 38 (2): 179-195.

Hollander, J. B., and J. Nemeth. 2011. “The Bounds of Smart Decline: A Foundational Theory for Planning Shrinking Cities.” Housing Policy Debate 21 (3): 349-367.

Hospers, G.-J. 2011. “Place Marketing in Shrinking Europe: Some Geographical Notes.” Tijdschrift Voor Economische en Sociale Geografie 102 (3): 369-375.

Jakóbczyk-Gryszkiewicz, J. 1997. "Demographic Characteristics of Łódź." In A Comparative Study of Łodź and Manchester: Geographies of European Cities in Transition, edited by S. Liszewski and C. Young, 111-124. Łódź: University of Łódź Press.

James, J. 2012. Preservation and National Belonging in Eastern Germany: Heritage Fetishism and the Heimat Imaginary. Houndmills, NY: Palgrave Macmillan.

Jessen, J. 2012. “Conceptualizing Shrinking Cities - a Challenge for Planning Theory.” In Parallel Patterns of Shrinking Cities and Urban Growth, edited by R. Ganser, and R. Piro, 45-58. Burlington, VT: Ashgate.

Kaczmarek, S., J. Kazimierczak, L. Coudroy de Lille, L. Mongeard, C. Bouloc, M. Więckowski, M. Jędrusik, L. Coudroy de Lille, and A. Le Blanc. 2018. "Demolowanie terenów miejskich: synergia w badaniach geograficznych w Polsce i we Francji [Demolition of Urban Areas: Synergy in Geographical Research in Poland and France].” In Geografia. Wspólne idee, wspólne wizje. Sto lat wspótpracy polsko-francuskiej [Geography. Common Ideas, Shared Visions. A Hundred Years of Polish-French Cooperation], 97-114. Warsaw: Wydział Geografii i Studiów Regionalnych UW.

Kazimierczak, J. 2014a. "Kształtowanie przestrzeni publicznej miasta w kontekście rewitalizacji terenów poprzemysłowych w Manchesterze, Lyonie i Łodzi [Public Space Transitions in City Centre and Revitalzation of Post-Industrial Urban Areas in Manchester, Lyon and Łódź].” Studia Miejskie 16: 115-128.

Kazimierczak, J. 2014b. Wpływ Rewitalizacji Terenów Poprzemysłowych na Organizację Przestrzeni Centralnej w Manchesterze, Lyonie i Łodzi [The Impact of Revitalization of Post-Industrial Urban Areas on Central Space Organization in Manchester, Lyon and Łódź]. Łódź: Łódź University Press.

Kazimierczak, J., and P. Kosmowski. 2017. "In the Shadow of Urban Regeneration Megaproject: Urban Transitions of Downtown in Łódź, Poland.” Urban Development Issues 56 (4): 39-50.

Klassen, L. H. 1988. Economical Thought and Practice. Łódź: Łódź University Press.

Koziol, M. 2004. “The Consequences of Demographic Change for Municipal Infrastructure.” German Journal of Urban Studies 44 (1): 69-83.

Krzysztofik, R., M. Dymitrov, R. Szmytkie, I. Kantor-Pietraga, J. Pełka-Gościniak, and T. Spórna. 2015. "Environmental Hazards and Urban Abandonment: Case Studies and Typological Issues." Geografiska Annaler: Series B, Human Geography 97 (4): 291-308. 
Lehrer, U., and J. Laidley. 2008. “Old Mega-Projects Newly Packaged? Waterfront Redevelopment in Toronto." International Journal of Urban and Regional Research 32 (4): 786-803.

Lesthaeghe, R., and D. J. van de Kaa. 1986. Twee Demografische Transities?, 9-24 Bevolking: Groei en Kremp.

Lever, J., and C. Young. 1997. "The Economic Structure of Manchester." In A Comparative Study of Łodź and Manchester: Geographies of European Cities in Transition, edited by S. Liszewski and C. Young, 97-110. Łódź: University of Łódź Press.

Liszewski, S., S. Liszewski, and C. Young. 1997. "The Origins and Stages of Development of Industrial Łódź and the Łódź Urban Region.” In A Comparative Study of Łodź and Manchester: Geographies of European Cities in Transition, 11-34. Łódź: University of Łódź Press.

Marcińczak, Sz, M. Gentile, S. Rufat, and L. Chelcea. 2013. "Urban Geographies of Hesitant Transition: Tracing Socioeconomic Segregation in Post-Ceaşescu Bucharest.” International Journal of Urban and Regional Research 38 (4): 1399-1417.

Martinez-Fernandez, C., I. Audirac, S. Fol, and E. Cunningham-Sabot. 2012. "Shrinking Cities: Urban Challenges of Globalization.” International Journal of Urban and Regional Research 36: 213-225.

Martinez-Fernandez, C., T. Weyman, S. Fol, I. Audirac, E. Cunningham-Sabot, T. Wiechmann, and H. Yahagi. 2016. "Shrinking Cities in Australia, Japan, Europe and the USA: From a Global Process to Local Policy Responses." Progress in Planning 105: 1-48.

Monclús, J., and C. Díez Medina. 2016. "Modernist Housing Estates in European Cities of the Western and Eastern Blocks.” Planning Perspectives 31 (4): 533-562.

Musterd, S., and M. Bontje. 2012. "Understanding Shrinkage in European Regions.” Built Environment 38: 196-312.

Novák, J., and L. Sýkora. 2007. "A City in Motion: Time-Space Activity and Mobility Patterns of Suburban Inhabitants and the Structuration of the Spatial Organization of the Prague Metropolitan Area." Geografiska Annaler: Series B, Human Geography 89 (2): 147-167.

Nuissl, H., and D. Rink. 2005. “The 'Production' of Urban Sprawl in Eastern Germany as a Phenomenon of PostSocialist Transformation." Cities 22: 123-134.

Ogrodowczyk, A., and Sz Marcińczak. 2014. "Łódź - od polskiego Manchesteru do polskiego Detroit [Łódź - from Polish Manchester to Polish Detroit?].” In Kurczenie się miast w Europie Srodkowo-Wschodniej [Shrinking Cities in Central Eastern Europe], edited by T. Stryjakiewicz, 79-88. Poznań: Bogucki Wydawnictwo Naukowe.

Orueta, F. D., and S. Fainstein. 2008. “The New Mega-Projects: Genesis and Impacts.” International Journal of Urban and Regional Research 32 (4): 759-767.

Oswalt, P., and T. Rieniets. eds. 2006. Atlas of Shrinking Cities. Ostfildern: Hatje Cantz.

Pallagst, K., R. Fleschurz, and S. Said. 2017. "What Drives Planning in a Shrinking City? Tales from two German and Two American Cases.” Town Planning Review 88 (1): 15-28.

Radzimski, A. 2016. "Changing Policy Responses to Shrinkage: The Case of Dealing with Housing Vacancies in Eastern Germany.” Cities 50: 197-205.

Reckien, D., and C. Martinez-Fernandez. 2011. "Why Do Cities Shrink?.” European Planning Studies 19: $1375-1397$.

Sjöberg, Ö. 2014. "Cases Onto Themselves? Theory and Research on Ex-Socialist Urban Environments." Geografie 119 (4): 299-319.

Śleszyński, P. 2005. “Różnice liczby ludności ujawnione w Narodowym Spisie Powszechnym 2002 [Differences in the Number of People Revealed in the National Census 2002].” Przegląd Geograficzny 77 (2): 193-212.

Smith, N., and J. DeFilippis. 1999. "The Reassertion of Economics: 1990s Gentrification on the Lower East Side." International Journal of Urban and Regional Research 23: 638-653.

Špačková, P., N. Dvořácková, and M. Tobrmanová. 2016. "Residential Satisfaction and Intention to Move: The Case of Prague's New Suburbanities.” Geografiska Annaler: Series B, Human Geography 98 (4): 331-348.

Strategy for spatial development of Łódź 2020+. 2014. Łódź: Łódź City Council.

Stryjakiewicz, T. 2013. “The Process of Urban Shrinkage and Its Consequences.” Romanian Journal of Regional Science 7: $29-40$.

Stryjakiewicz, T., P. Ciesiółka, and E. Jaroszewska. 2012. "Urban Shrinkage and the Post-Socialist Transformation: The Case of Poland." Built Environment 38: 197-213.

Stryjakiewicz, T., E. Jaroszewska, Sz Marcińczak, A. Ogrodowczyk, P. Rumpel, T. Siwek, and O. Slach. 2014. "Współczesny kontekst i podstawy teoretyczno-metodologiczne analizy procesu kurczenia się miast [Current Contects and Teoretical and Methodological Basis of Urban Shrinkage Analysis]." In Kurczenie się miast $w$ Europie Środkowo-Wschodniej [Shrinking Cities in Central Eastern Europe], edited by T. Stryjakiewicz, 9-14. Poznań: Bogucki Wydawnictwo Naukowe.

Sýkora, L. 2009. "Post-socialist Cities." In International Encyclopedia of Human Geography, edited by R. Kitchin and N. Thrift, 387-395. Oxford: Elsevier.

Szafrańska, E. 2013. "Large Housing Estates in Post-Socialist Poland as a Housing Policy Challenge.” European Spatial Research and Policy 20 (1): 119-129.

Szafrańska, E. 2014. “Transformations of Large Housing Estates in Post-Socialist City: The Case of Łódź, Poland.” Geographia Polonica 87 (1): 77-93. 
Szafrańska, E., L. Coudroy de Lille, and J. Kazimierczak. 2018. "Urban Shrinkage and Housing in a Post-Socialist City: Relationship Between the Demographic Evolution and Housing Development in Łódź, Poland." Journal of Housing and the Built Environment. https://link.springer.com/article/10.1007/s10901-018-9633-2.

Szelényi, I. 1996. "Cities Under Socialism and After." In Cities After Socialism. Urban and Regional Change and Conflict in Post-Socialist Societies, edited by G. Andrusz, M. Harloe, and I. Szelényi, 286-317. Oxford: Blackwell Publishers.

Temelová, J., J. Novák, A. Kährik, and T. Tammaru. 2016. "Neighborhood Trajectories in the Inner Cities of Prague and Tallin: What Affects the Speed of Social and Demographic Change?" Geografiska Annaler: Series B, Human Geography 98 (4): 349-366.

Thomsen, A., and K. van der Flier. 2009. "Replacement or Renovation of Dwellings: the Relevance of a More Sustainable Approach." Building Research \& Information 37 (5-6): 649-659.

Thomsen, A., and K. van der Flier. 2011. "Understanding Obsolescence: A Conceptual model for Buildings." Building Research \& Information 39 (4): 352-362.

Turok, I. 1992. "Property-Led Urban Regeneration: Panacea or Placebo?” Environment and Planning A 24 (3): 361379.

Turok, I., and V. Mykhnenko. 2007. “The Trajectories of European Cities, 1960-2005.” Cities (london, England) 24 (3): $165-182$.

Turok, I., and V. Mykhnenko. 2008. "East European Cities - Patterns of Growth and Decline, 1960-2005." International Planning Studies 13 (4): 311-342.

Van de Kaa, D. J. 2003. "The Idea of a Second Demographic Transition in Industrialized Countries." Japanese Journal of Population 1: 42-75.

Weber, R., M. Doussard, S. Dev Bhatta, and D. McGrath. 2006. "Tearing the City Down: Understanding Demolition Activity in Gentyfying Neighborhoods." Journal of Urban Affairs 28 (1): 19-41.

Wiechmann, T. 2009. "Conversion Strategies Under Uncertainty in Post-Socialist Shrinking Cities - The Example of Dresden in Eastern Germany." In The Future of Shrinking Cities - Problems, Patterns and Strategies of Urban Transformation in a Global Context, edited by K. Pallagst, et al., 5-16. Center for Global Metropolitan Studies, Institute of Urban and Regional Development, and the Shrinking Cities International Research Networks, University of California.

Wiechmann, T., and M. Bontje. 2015. "Responding to Tough Times: Policy and Planning Strategies in Shrinking Cities." European Planning Studies 23 (1): 1-11.

Wiechmann, T., and K. M. Pallagst. 2012. "Urban Shrinkage in Germany and the USA: A Comparison of Transformation Patterns and Local Strategies." International Journal of Urban and Regional Research 36: 261-280.

Yin, R. K. 2014. Case Study Research: Design and Methods. London: Sage.

Young, C., and S. Kaczmarek. 2008. "The Socialist Past and Postsocialist Urban Identity in Central and Eastern Europe. The Case of Łódź, Poland." European Urban and Regional Studies 15: 53-70. 